\title{
Wyksztalcenie zawodowe \\ - miejsce w systemie edukacji i na rynku pracy
}

DOI: 10.47050/65591814.24-65

Urszula Sztanderska, Gabriela Grotkowska

W rozdziale przedstawiono analizę miejsca osób ze średnim i zasadniczym wykształceniem zawodowym na rynku pracy w Polsce. W tym zakresie zestawiono popyt na pracę z jej podażą, tzn. kształceniem i z wykorzystaniem zasobów pracy (aktywnością, bezrobociem i zatrudnieniem, ogółem i w przekroju zawodowym oraz według płci). Pokazano w nim także rozmieszczenie osób z wykształceniem zawodowym między miastami różnej wielkości i wsią oraz strukturę według dziedzin kształcenia.

W rozdziale dowiedziono, że zasób osób z wykształceniem zasadniczym maleje i będzie malał w przyszłości wskutek niepodejmowania kształcenia na tym poziomie, a także, że istnieje obiektywne uzasadnienie takich decyzji. W konsekwencji powstaje niedostosowanie między popytem i podażą, pogłębione przez nierównomierne rozmieszczenie zasobów między miastami i wsią. Jego efektem jest permanentny niedobór kandydatów do pracy na stanowiskach robotniczych.

\section{Słowa kluczowe:}

wykształcenie zawodowe

popyt na pracę

podaż pracy

zatrudnienie

Polska 


\section{Vocational education \\ - role in the education system and on the labour market}

DOI: $10.47050 / 65591814.24-65$

Urszula Sztanderska, Gabriela Grotkowska

The chapter focuses on the analysis of the position of individuals with vocational secondary and basic education on the Polish labour market. It compares the labour demand labour supply, i.e. education and the use of human resources (economic activity, unemployment and employment, in general and in different profiles). The chapter documents the distribution of individuals with vocational education between cities of different sizes and rural areas, and their structure by field of education.

The chapter provides evidence that the number of individuals with basic education is decreasing and will decrease in the future as a result of not undertaking this type of education, as well as that there is objective justification for such decisions. Consequently, there is a mismatch between supply and demand, accompanied with an uneven distribution of resources between cities and the rural areas. It results in a permanent shortage of candidates for workers' positions.

\section{Keywords:}

vocational education

labour demand

labour supply

employment

Poland 
Pierwsze dwie dekady polskiej transformacji przyniosły - jeśli chodzi o strukturę wykształcenia ludności - przede wszystkim wzrost zainteresowania podejmowaniem studiów wyższych. Zjawisko to, powszechne we wszystkich krajach postsocjalistycznych (Kogan i in. 2008), wiązało się z wyraźnie lepszymi niż przeciętne wynikami rynku pracy, w tym z lepszymi perspektywami uzyskania zatrudnienia i z wyższymi wynagrodzeniami, dla tej grupy osób, które skończyły studia, w przeciwieństwie do pozostałych. Znalazło to odbicie w literaturze, gdzie wielokrotnie dokumentowano premię z wykształcenia wyższego czy procesy związane ze zmianą wzorców wyborów edukacyjnych. Mniej miejsca $w$ dyskursie publicznym poświęcano kształceniu zawodowemu, co niejako było odzwierciedleniem spadku liczby uczniów wybierających szkoły zawodowe, zmniejszenia liczby tych szkół, a przede wszystkim - słabszych wyników na rynku pracy dla absolwentów z wykształceniem zawodowym (trudności w znalezieniu pracy czy relatywnie niskie płace). Zjawiska te, widoczne również w niektórych innych państwach przechodzących transformację, prowadziły do zwiększenia częstości kształcenia ogólnego na poziomie średnim w miejsce zawodowego (Kogan i in. 2008). W konsekwencji podaż osób z wykształceniem zawodowym malała. Dodatkowo, w związku ze wzrostem skali emigracji zarobkowej z Polski, po przystąpieniu Polski do Unii Europejskiej z coraz większą siłą ujawniały się deficyty na rynku pracy, w szczególności w obszarze zawodów typowych dla średnich i niskich kwalifikacji zawodowych. Można to wiązać z ponadprzeciętnym zainteresowaniem emigracją zarobkową osób przygotowanych do pracy na stanowiskach robotniczych (Duszczyk, Wiśniewski 2007).

Zarazem rosnąca grupa pracodawców niemal stale deklarowała trudności w znalezieniu odpowiednich pracowników ze średnim i zasadniczym wykształceniem zawodowym. Pewną rolę w powstawaniu trudności w zaspokojeniu popytu na pracowników odgrywa sposób funkcjonowania systemu kształcenia niepozwalający na zaspokojenie popytu na pracę $w$ tym segmencie rynku. Należy podkreślić, że bardzo istotnym czynnikiem upośledzającym podaż pracy jest relatywnie niski poziom płac w Polsce dla osób z wykształceniem zawodowym. Deficytom występującym na rynku pracy w obsadzie stanowisk robotniczych i przeznaczonych dla osób o średnim poziomie kwalifikacji nie towarzyszył na tyle istotny wzrost płac, żeby znacząco zwiększyć dopływ pracowników o odpowiednim poziomie kompetencji. Płace nie- 
dostosowujące się do rzadkości zasobów pracy (luki między zgłaszanym popytem a podażą pracy) dla osób o wykształceniu średnim i zasadniczym zawodowym ograniczają podaż pracy, co okazuje się szczególnie istotne w warunkach wprowadzania nowych świadczeń socjalnych. Przy stosunkowo niskich płacach tym bardziej powodują one zmniejszanie liczby chętnych do wykonywania prac niewymagających wykształcenia wyższego (Myck 2016).

Celem niniejszego rozdziału jest przekrojowe przedstawienie sytuacji osób z wykształceniem zawodowym w Polsce w okresie od przystąpienia Polski do Unii Europejskiej aż do okresu bieżącego (najczęściej był to 2017 r. lub I kwartał 2018 r., dla których dysponowaliśmy pełnymi danymi). Ujęcie to pozwoli na porównanie, jaką pozycję ma wykształcenie zawodowe na polskim rynku pracy z tym, jak się je tworzy (co opisano w dalszych rozdziałach). W niniejszym rozdziale wykorzystano dane Głównego Urzędu Statystycznego (GUS), przede wszystkim pochodzące z Badania Aktywności Ekonomicznej Ludności (BAEL) za lata 2004-2017 (z zastosowaniem dostarczanych przez GUS wag, pozwalających na uogólnianie wyników na całą populację).

$W$ analizach przedstawionych $w$ rozdziale skupiono się na populacji w wieku 25-64 lata. Z uwagi na specyfikę procesu kształcenia, jego rozciągnięcie $w$ czasie oraz zróżnicowanie $w$ zależności od dokonanych wyborów edukacyjnych, dolną granicę wieku ustalono na 25 lat, a więc wiek, gdy dla większości osób proces kształcenia jest zakończony. Pozwala to na porównanie populacji osób o wykształceniu zawodowym z populacją osób z wyższym wykształceniem. Górna granica dotyczy dezaktywizacji zawodowej związanej z przechodzeniem na emeryturę. Z uwagi na to, że problem zróżnicowania wieku emerytalnego kobiet i mężczyzn nie jest tu przedmiotem szczególnego zainteresowania, 64 lata uznano za wspólną granicę dla obu płci. Wiadomo jednak, że w przypadku kobiet przypada ona na czas, kiedy mają one od kilku lat prawo do pobierania emerytur, w przypadku mężczyzn zaś jest to wiek poprzedzający nabycie tych praw. W części analiz wyróżniono też populację w wieku 25-34 lata, a więc grupę młodszych uczestników rynku pracy, którzy stosunkowo niedawno zakończyli kształcenie i przebywają na tym rynku stosunkowo krótko. Porównanie ich położenia z sytuacją populacji ogółem pozwala na wyciagnięcie wniosków co do zachodzących i spodziewanych zmian strukturalnych na krajowym rynku pracy. 


\section{Kształcenie zawodowe a popyt na prace}

Badania popytu na pracę GUS nieodmiennie od wielu lat wskazują na poszukiwanie przez pracodawców osób z wykształceniem zawodowym, przede wszystkim z zasadniczym zawodowym, na stanowiska robotników przemysłowych, operatorów maszyn i urządzeń oraz pracowników usług i sprzedawców, a także na stanowiska, które w większości wymagają posiadania średniego wykształcenia zawodowego techników i średniego personelu oraz pracowników biurowych. Sytuację pod tym względem dobrze ilustruje wykres 1 przedstawiający wyniki badania popytu na pracę w I kwartale 2018 r.

Konieczność rozwoju kształcenia na poziomie zasadniczym zawodowym i średnim zawodowym potwierdzają dane. Wynika z nich, że dominująca część ofert pracy przeznaczonych dla robotników, operatorów maszyn i urządzeń oraz pracowników usług i sprzedawców z wykształceniem zasadniczym zawodowym pozostaje nieobsadzona. Nie można znaleźć chętnych do objęcia 56,5\% istniejących oraz $49,1 \%$ nowo tworzonych stanowisk. W przypadku samych robotników i rzemieślników wskaźniki te wynoszą, odpowiednio, 27,8\% i 24,3\%. W przypadku pracowników wykonujących wymienione wyżej zawody, ale mających wykształcenie średnie, wskaźniki są nieco inne. Nie udaje się obsadzić $16,3 \%$ oferowanych im miejsc pracy (w przypadku nowo utworzonych stanowisk jest to 15,4\%). Zdaniem osób wypowiadających się w dyskursie publicznym, w tym przedstawicieli Ministerstwa Edukacji, rozwój szkolnictwa zawodowego powinien dokonać się zwłaszcza przez ograniczenie średniego kształcenia ogólnego. Nie wszyscy bowiem absolwenci szkół ogólnokształcących kontynuują edukację na studiach i jeśli nie odbędą przeszkolenia zawodowego - są zagrożeni bezrobociem. 


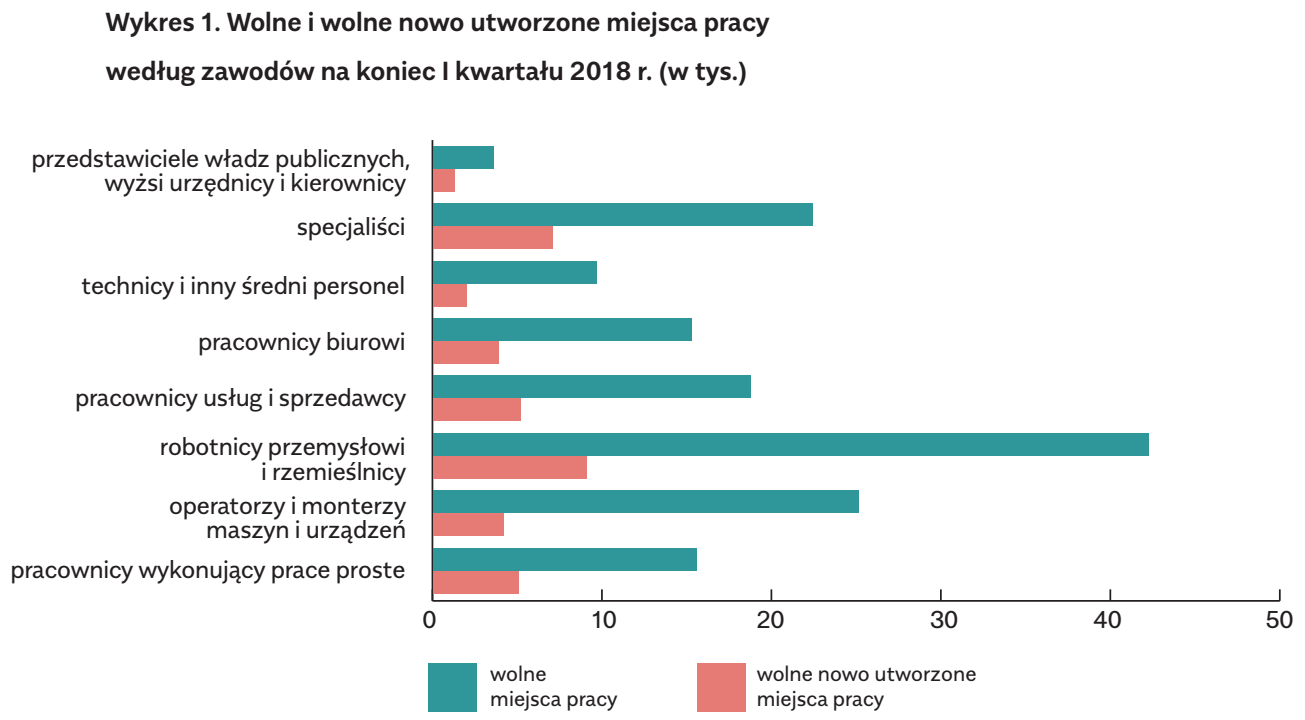

Źródło: Popyt na pracę... 2018, s. 3.

Może zaskakiwać, że w stosunkowo długim okresie, bo począwszy od 2005 r. (pierwszy rok systematycznych badań popytu na pracę GUS, wykres 2) aż do 2018 r., mimo głębokich zmian gospodarczych, jakie dokonały się w tym czasie, struktura wolnych miejsc pracy i wolnych nowo utworzonych miejsc pracy pozostawała prawie taka sama (współczynniki korelacji Pearsona wynosiły, odpowiednio, 0,92 i 0,88). Czyli 13 lat wcześniej również nieskutecznie poszukiwano głównie robotników, rzemieślników i operatorów maszyn i urządzeń (wolne miejsca dla samych tylko robotników i rzemieślników stanowiły 30,1\%, w tym nowo utworzone $28,3 \%$ ). Luka podażowa wydaje się przy tym obecnie bardziej dotkliwa, ponieważ ogólne zapotrzebowanie na pracowników, których nie udało się znaleźć w 2013 r., sięgało 152 tys. osób, natomiast w 2004 r. tylko 44 tys. Zasadniczo zatem popyt na pracę wzrósł, jego struktura zaś z perspektywy zapotrzebowania na kwalifikacje zawodowe nie zmieniała się znacząco. Można nawet zauważyć niewielkie zmniejszenie udziału nieobsadzonych miejsc pracy dla osób z wykształceniem zasadniczym zawodowym. Ich obecnie duża liczba to zatem głównie efekt ogólnego wzrostu popytu na pracę, a nie 
szczególnego zwiększenia zapotrzebowania na pracę na stanowiskach robotniczych, rzemieślniczych czy operatorskich.

Nietrudno jednak zauważyć, że ograniczony dopływ kadr do tworzonych miejsc pracy wymagających wykształcenia zawodowego na poziomie zasadniczym i, w mniejszym stopniu, średnim musi być wynikiem utrzymywania się stosunkowo mało atrakcyjnych warunków pracy dla tych grup. Ewentualny wzrost płac spowodowałby bowiem przepływ kadr na te stanowiska ze stanowisk wyższych w hierarchii zawodowej i stanowiłby zachętę do podejmowania kształcenia w technikach i zasadniczych szkołach zawodowych. Kluczowe pytanie zatem brzmi: czy "nadwyżkowe" miejsca pracy dla osób z wykształceniem zawodowym utrzymałyby się, gdyby wynagrodzenia w miejscach ich pracy $i-w$ ślad za tym - koszty pracy wzrosły? Nadwyżki te - póki istnieją - świadczą też zatem o systematycznie utrzymującej się nierównowadze w obrębie rynku pracy i o nieadekwatności wynagrodzeń do poziomów zapewniających równowagę.

Wykres 2. Wolne i wolne nowo utworzone miejsca pracy

według zawodów w 2005 r. (w tys.)

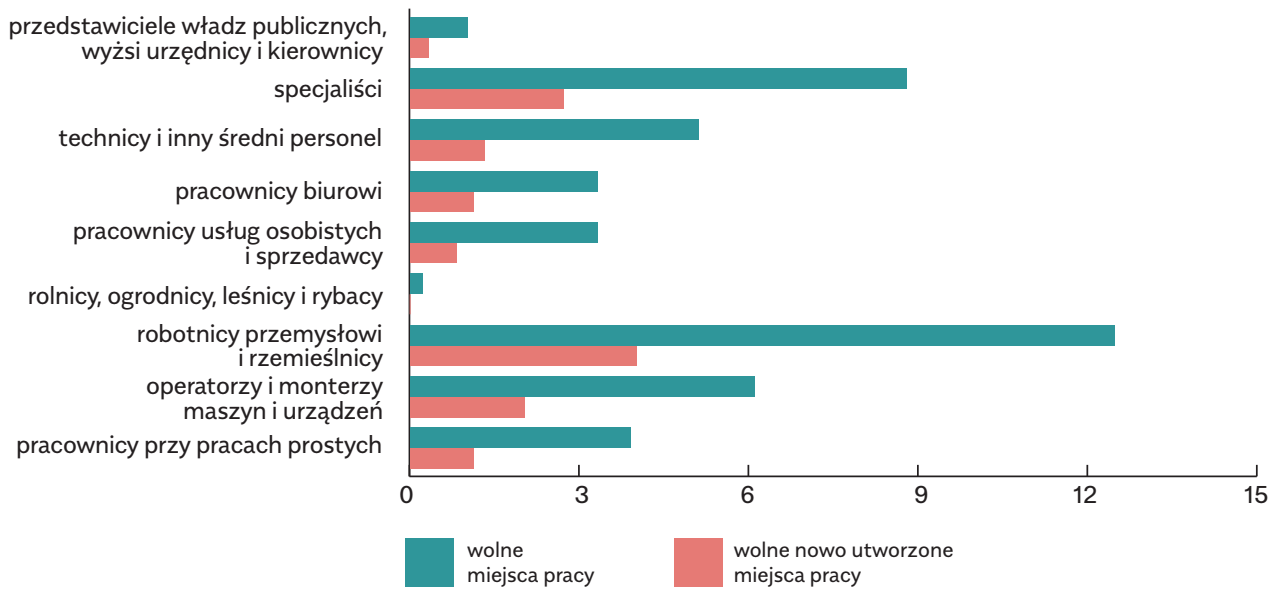

Źródło: Popyt na pracę... 2005, tab. 13 i 21 


\section{Czy wykształcenie wyższe jest bardziej atrakcyjne od zawodowego?}

Umocniło się też przekonanie, że wykształcenie wyższe przynosi coraz mniejsze korzyści. Pogląd ten jest przynajmniej częściowo udokumentowany w literaturze naukowej, gdzie dla lat 1995-2009 opisano spadek względnych korzyści z wykształcenia wyższego w postaci niższej premii płacowej w porównaniu z wykształceniem średnim, w dużym stopniu wynikający z podejmowania pracy w grupach zawodów w zasadzie wymagających niższego wykształcenia niż wykształcenie wyższe (Gajderowicz, Grotkowska, Wincenciak 2012). Liczba miejsc pracy dla specjalistów (2. grupa Międzynarodowej Standardowej Klasyfikacji Kształcenia - ISCED) nie nadążała za podażą absolwentów uczelni, zwłaszcza kierunków społecznych i ekonomicznych. W efekcie część z nich podejmowała pracę na stanowiskach o mniejszych wymaganiach kwalifikacyjnych, gdzie pracowały głównie osoby z wykształceniem średnim, i uzyskiwała na nich płace wyższe niż ci ostatni. Jednak nasycenie kadrami z wyższym wykształceniem rzeczywiście obniżało ich względne płace. Inne badania wskazują, że nie występuje wyraźnie jednokierunkowy trend zmian w korzyściach z wykształcenia i np. w 2010 r. w stosunku do 2008 r., po latach spadku, nastąpił ich wzrost ${ }^{1}$ (Majchrowska, Roszkowska 2013).

Nagłośnione obserwacje o mniejszych niż na początku XXI w. korzyściach z wyższego wykształcenia umacniają $w$ dyskursie publicznym postawę, że przede wszystkim należy rozwijać kształcenie zawodowe. W powiązaniu ze zgłaszanym dużym popytem na pracę, skierowanym do tej grupy, każą podejmować działania na rzecz szkolnictwa zawodowego. Nic nie ujmując wadze dobrego wykształcenia zawodowego (o właściwej strukturze, dobrej kompozycji kompetencji szczegółowych), zawsze można sceptycznie podchodzić do tego, czy nieobsadzone miejsca pracy dobrze ilustrują rynkowe braki osób z takim wykształceniem, gdyż korzyści z wyższego wyksztalcenia ciągle przeważają nad jego kosztami, nawet jeśli uwzględnić efekt selekcji (Wincenciak 2017). Większości studiowanie po prostu się opłaca, nie dziwi więc wybór szkół

Analizując zmiany premii za kolejny etap wykształcenia w czasie, można zauważyć, że w latach 2004-2008 na każdym poziomie zmniejszyła się ona. W 2010 r. nastapił wzrost premii za wykształcenie zawodowe, średnie techniczne i wyższe. Nie wzrosła natomiast premia za wykształcenie średnie ogólnokształcące, która w całym analizowanym okresie utrzymywała się na bardzo niskim poziomie (Majchrowska, Roszkowska 2013). 
ogólnokształcących po zakończeniu gimnazjów, dzięki czemu stosunkowo łatwiej podjąć studia. Niemniej dość niskie pozostają korzyści z wykształcenia średniego ogólnokształcącego. Zatem rynek doceniał głównie osoby posiadające przygotowanie zawodowe.

\section{Struktura wyksztalcenia ludności}

W strukturze ludności ( $w$ wieku 25-64 lata, a więc w wieku, kiedy zasadnicza część osób ukończyła edukację formalną, a zarazem istnieje znaczne prawdopodobieństwo aktywności zawodowej) od 2016 r. najliczniejszą grupą stały się osoby z wyższym wykształceniem, stanowiące w 2017 r. przeszło $30 \%$. W tym samym roku osób z wykształceniem zasadniczym zawodowym było niecałe $28 \%$, a ze średnim zawodowym $22 \%$. Jeszcze 13 lat wstecz udział osób posiadających wyższe wykształcenie był niemal o połowę niższy (o 15 pkt. proc.), zaś udział dysponujących wykształceniem zawodowym zasadniczym o 7 pkt. proc. wyższy. W stosunkowo niewielkim stopniu natomiast zmieniał się udział osób z wykształceniem średnim zawodowym, różnica w tym wypadku jest mniejsza niż 1 pkt. proc. Radykalna zmiana zaszła też w populacji posiadającej co najwyżej wykształcenie gimnazjalne - udział osób $z$ takim wykształceniem zmalał o ponad 8 pkt. proc. Kluczowe zmiany w strukturze wykształcenia dotyczyły więc udziałów osób z wykształceniem wyższym, zasadniczym zawodowym i nieposiadających przynajmniej wykształcenia zasadniczego.

Tabela 1. Populacja w wieku 15-64 lata według poziomu wykształcenia (w \%)

\begin{tabular}{c|c|c|c|c|c|c} 
rok & wyższe & policealne & $\begin{array}{c}\text { średnie } \\
\text { zawodowe }\end{array}$ & $\begin{array}{c}\text { średnie } \\
\text { ogólne }\end{array}$ & $\begin{array}{c}\text { zasadnicze } \\
\text { zawodowe }\end{array}$ & $\begin{array}{c}\text { gimnazjalne } \\
\text { i niższe }\end{array}$ \\
\hline 2004 & 15,87 & 3,53 & 23,18 & 7,60 & 33,79 & 16,03 \\
\hline 2008 & 19,71 & 3,65 & 23,41 & 7,74 & 32,88 & 12,61 \\
\hline 2012 & 24,72 & 3,68 & 22,69 & 8,16 & 30,55 & 10,21 \\
\hline 2016 & 28,94 & 3,37 & 22,69 & 8,20 & 28,24 & 8,55 \\
\hline 2017 & 30,13 & 3,41 & 22,42 & 8,44 & 27,84 & 7,77
\end{tabular}


Zmiany te powiększyły udział osób z szeroko rozumianym wykształceniem zawodowym - jeśli uwzględnić w tym nie tylko wykształcenie średnie i zasadnicze, ale i wyższe. Niemniej jednak osoby bez wykształcenia zawodowego stanowią wciąż znaczną część zasobów pracy- ponad $16 \%$, z czego ok. $8,5 \%$ z wykształceniem licealnym, a ponad $7,5 \%$ $z$ wykształceniem co najwyżej gimnazjalnym.

Tabela 2. Populacja w wieku 25-34 lata według poziomu wykształcenia (w \%)

\begin{tabular}{c|c|c|c|c|c|c} 
rok & wyższe & policealne & $\begin{array}{c}\text { średnie } \\
\text { zawodowe }\end{array}$ & $\begin{array}{c}\text { średnie } \\
\text { ogólne }\end{array}$ & $\begin{array}{c}\text { zasadnicze } \\
\text { zawodowe }\end{array}$ & $\begin{array}{c}\text { gimnazjalne } \\
\text { i niższe }\end{array}$ \\
\hline 2004 & 23,54 & 3,94 & 23,44 & 8,86 & 31,71 & 8,51 \\
\hline 2008 & 32,26 & 4,32 & 22,11 & 9,43 & 24,81 & 7,07 \\
\hline 2012 & 40,80 & 3,84 & 21,02 & 11,19 & 17,59 & 5,57 \\
\hline 2016 & 43,19 & 3,27 & 21,17 & 12,09 & 14,47 & 5,81 \\
\hline 2017 & 42,98 & 3,07 & 21,03 & 13,10 & 14,24 & 5,57
\end{tabular}

Źródło: obliczenia własne na podstawie danych indywidualnych BAEL.

To jest potencjał, który mógłby zasilić grupy osób z wykształceniem zasadniczym lub średnim zawodowym, jeśli uzyskano by redukcję osób niekontynuujących kształcenia po gimnazjum lub szkole podstawowej, a także gdyby część osób niepodejmujących studiów skierowała swoje kroki nie do liceów ogólnokształcących, a do techników.

Waga tego problemu nie zmniejszyła się w najmłodszym pokoleniu na rynku pracy (w wieku 25-34 lata, tabela 2). Wręcz odwrotnie, udział osób bez wykształcenia zawodowego w tej populacji jest jeszcze większy, a to za sprawą ponad $13 \%$ osób z wykształceniem ogólnokształcącym, które nie podjęły ani studiów, ani kształcenia policealnego, a których udział w latach 2014-2013 zwiększył się o 4 pkt. proc. I to mimo równoczesnego zwiększenia liczby osób z wyższym wykształceniem, aż o 19,5 pkt. proc., i tylko przy nieznacznym (mniejszym niż 1 pkt proc.) zmniejszeniu udziału osób z wykształceniem policealnym. Świadczy to o tym, że najmłodsi, wchodzący na rynek pracy po 2004 r., podejmowali naukę w liceach ogólnokształcących w liczbie przekraczającej tę, która podejmowała dalsze kształcenie. Gdyby ta "nadwyżka" zdobyła wykształcenie zawodowe - średnie lub zasadnicze - spadek udziału 
osób wchodzących z tym wykształceniem na rynek pracy nie byłby tak dotkliwy. A tak wyniósł on prawie 20 pkt. proc. (o 17,5 pkt. proc. zmalał udział osób posiadających wykształcenie zasadnicze i o 2,5 pkt. proc. posiadających wykształcenie średnie zawodowe).

Powyższe dane wskazują, że udział osób z wykształceniem zawodowym (łącznie: średnim, zasadniczym i policealnym) w 2017 r. zamiast $33,6 \%$ sięgałby 49,8\%, gdyby osoby, które odbyły naukę w liceach ogólnokształcących, a nie podjęły/nie ukończyły studiów, po gimnazjach skierowały swoje kroki do szkół zawodowych i gdyby każdy kończący gimnazjum ukończył zasadniczą szkołę zawodową. Ich udział i tak byłby mniejszy niż w 2004 r., lecz luka w kształceniu zawodowym zmniejszyłaby się istotnie.

Częstotliwość posiadania wyższego wykształcenia wśród osób w wieku 25-34 lata, w porównaniu z całą populacją (wiek 25-64 lata), rosła do ok. 2012 r., po czym zaczęła spadać, co wskazuje, że nasycanie kadrami z tym poziomem wykształcenia stopniowo stabilizuje się. Zapewne w odleglejszej perspektywie najmłodsi będą cechowali się zbliżonym (lub niewiele większym) do najstarszych udziałem osób z wyższym wykształceniem. Tymczasem osób posiadających wykształcenie średnie ogólne jest w najmłodszej generacji coraz więcej w stosunku do całej populacji. I trudno byłoby dostrzec tu jakiś trend stabilizacyjny. $Z$ kolei udział osób ze średnim wykształceniem zawodowym i z wykształceniem policealnym powoli maleje. Nie są to jednak zmiany duże. Natomiast odwrót od kształcenia zasadniczego zawodowego jest bardzo widoczny przez cały okres 2004-2017, a nawet nasila się on (tabela 3). Nowe roczniki wchodzące na rynek pracy w dużo mniejszym stopniu dysponują takim przygotowaniem do podjęcia pracy. $Z$ jednej strony stoi to w jaskrawej opozycji do zgłaszanego przez pracodawców popytu na pracę, z drugiej zaś wyjaśnia, dlaczego tak wiele wakatów przeznaczonych dla osób z takim wykształceniem pozostaje nieobsadzonych. I wskazuje, że wynagrodzenia są zbyt mało elastyczne, by odzwierciedlać deficyt osób z wykształceniem zasadniczym na rynku pracy. Być może u podłoża tej niskiej elastyczności leży nie tylko sam mechanizm stanowienia płac, ale także niska produktywność pracy na stanowiskach oferowanych tej grupie potencjalnych pracowników. 
Tabela 3. Stosunek udziału osób o danym wykształceniu w wieku 25-34 lata

do udziału osób o danym wykształceniu w wieku 25-64 lata

\begin{tabular}{c|c|c|c|c|c|c} 
rok & wyższe & policealne & $\begin{array}{c}\text { średnie } \\
\text { zawodowe }\end{array}$ & $\begin{array}{c}\text { średnie } \\
\text { ogólne }\end{array}$ & $\begin{array}{c}\text { zasadnicze } \\
\text { zawodowe }\end{array}$ & $\begin{array}{c}\text { gimnazjalne } \\
\text { i niższe }\end{array}$ \\
\hline 2004 & 1,483 & 1,116 & 1,011 & 1,166 & 0,939 & 0,531 \\
\hline 2008 & 1,636 & 1,183 & 0,944 & 1,219 & 0,755 & 0,561 \\
\hline 2012 & 1,651 & 1,044 & 0,926 & 1,372 & 0,576 & 0,545 \\
\hline 2016 & 1,492 & 0,968 & 0,933 & 1,475 & 0,512 & 0,680 \\
\hline 2017 & 1,427 & 0,901 & 0,938 & 1,553 & 0,511 & 0,717
\end{tabular}

Źródło: obliczenia własne na podstawie danych indywidualnych BAEL.

Spadek udziału osób zdobywających na szczeblu ponadgimnazjalnym wykształcenie zawodowe może również wynikać z ograniczania dostępności miejsc w szkołach zawodowych. To z kolei wiąże się z polityką samorządów powiatowych i miast na prawach powiatu, które są zobowiązane do kształcenia na tym poziomie i w "naturalny" sposób chętnie oferowały kształcenie tańsze, czyli ogólnokształcące, zamiast zawodowego. Bodźcem do tego ograniczania była bez wątpienia nieróżnicowana waga przypisana uczniom wszystkich szkół ponadgimnazjalnych w algorytmie podziału środków oświatowej części subwencji ogólnej trafiającej do samorządów, podczas gdy koszty kształcenia były zdecydowanie wyższe w szkołach zawodowych. Z brakiem tego zróżnicowania mieliśmy do czynienia aż do 2000 r. Później zaś, choć waga pojawiła się, to w niedostatecznym stopniu uwzględniała koszt kształcenia zawodowego - w 2004 r. sięgała ona 0,15, została zaś zwiększona do 0,17 w 2009 i do 0,19 w 2010 r. (Raport o stanie edukacji... 2011).

\section{Wyksztalcenie zawodowe kobiet i mężczyzn}

Stosunkowo mały udział osób z wykształceniem zasadniczym zawodowym wynika głównie z tego, że jest ich mało wśród kobiet - zaledwie $21,1 \%$. Wśród mężczyzn natomiast udział ten wynosi $34,6 \%$. Wpływa to przede wszystkim na podaż pracy kobiecej w zawodach robotniczych. Może to być następstwem wycofywania się przez kobiety z kształcenia w takich - niegdyś typowych dla nich - kierunkach, które zapewniały pracę $w$ przemyśle, $w$ tym $w$ gałęziach zdominowa- 
nych przez kobiety, jak np. włókiennictwo, przemysł odzieżowy, radiotechniczny, farmaceutyczny (Rocznik Statystyczny Przemysłu 2017, tab. 3 (50)). Występująca w Polsce segregacja zawodowa może sprawiać, że kobiety poszukują pracy w tych zawodach, w których są już licznie reprezentowane. Redukcja kobiecego zatrudnienia może wiązać się ze zmianą struktury produkcji przemysłowej, a zatem może podlegać oddziaływaniu popytu na pracę. Ten zaś zwrotnie wpływa na decyzje edukacyjne i wycofywanie się kobiet z kształcenia zasadniczego. Udział osób z wykształceniem średnim zawodowym w populacji 25-64 lata jest dość zrównoważony, mężczyzn tak wykształconych jest wprawdzie nieco więcej niż kobiet, lecz różnica ta nie jest bardzo duża. Sugeruje to, że osoby obu płci znajdują w tym kształceniu szanse dla siebie (wykres 3).

Wykres 3. Struktura wykształcenia kobiet i mężczyzn w wieku 25-64 lata w 2017 r.

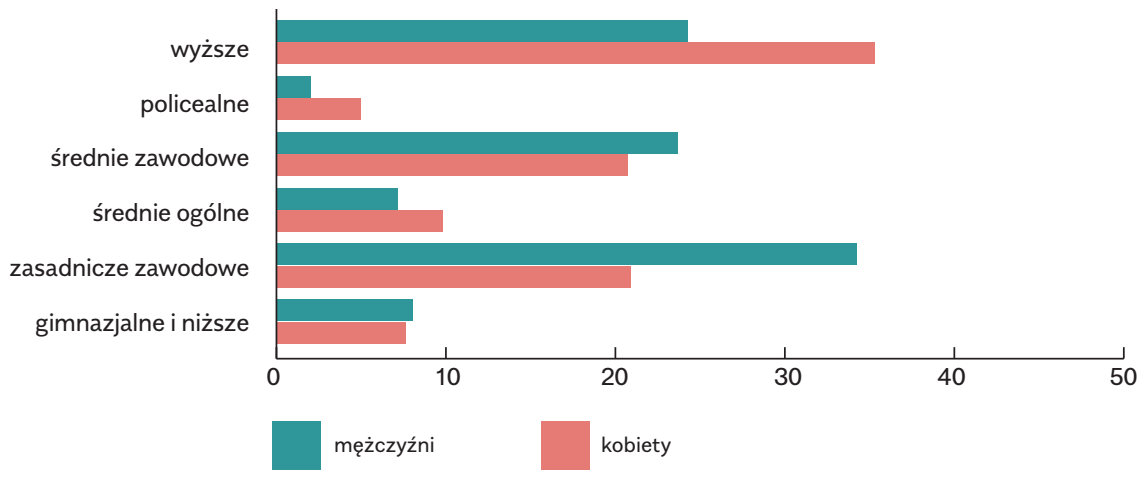

Źródło: obliczenia własne na podstawie danych indywidualnych BAEL.

Wśród osób obu płci występują takie, które nie mają żadnego formalnego przygotowania zawodowego. Ich udział w populacji kobiet i mężczyzn prawie się nie różni. Osoby te są swoistym, potencjalnym „rezerwuarem" do kształcenia zasadniczego zawodowego, o ile udałoby się je do tego przekonać. Nie oznacza to, że są one gotowe podjąć takie kształcenie. Przykładowo, nie zawsze jest to możliwe ze względu na wiek, stan zdrowia czy motywacje. $Z$ drugiej strony trzeba też przyjąć, że w gospodarce występuje pewien, niemały, wnioskując na podstawie 
danych z wykresu 1, popyt na wykonawców prac prostych, którzy mogą rekrutować się z tej grupy osób bez przygotowania zawodowego. Inaczej ma się sprawa z osobami, które ukończyły licea ogólnokształcące i nie kontynuowały nauki. Częściej są to kobiety, dość liczne, bo stanowiące prawie $10 \%$ populacji żeńskiej, ale też i mężczyźni z udziałem $7 \%$.

Analiza struktury wykształcenia młodych osób (w wieku 25-34 lata) pozwala oszacować, jakich trendów na rynku pracy można się spodziewać. Struktura ta jest dla kobiet i mężczyzn zasadniczo różna. O ile wśród kobiet w wieku 25-34 lata już większość posiada dyplom ukończenia studiów wyższych, o tyle wśród mężczyzn udział osób legitymujących się takim dyplomem wynosi tylko 1/3. Zapamiętałe dążenie do uzyskania wyższego wykształcenia musiało odcisnąć piętno na tym, ile osób każdej z płci decydowało się na skończenie szkoły zawodowej, a ile wybrało kształcenie ogólnokształcące, stanowiące prostszą drogę do podjęcia studiów. W konsekwencji zróżnicowane udziały cechują obie płcie w zakresie wykształcenia zawodowego - mężczyźni w 25,4\% mają ukończoną średnią szkołę zawodową, a kobiety tylko w $16,4 \%$ (9 pkt. proc. różnicy), mężczyźni w 18,5\% są absolwentami zasadniczych szkół zawodowych, a kobiety tylko w 9,7\% (też prawie 9 pkt. proc. różnicy). Kobiety częściej zaś dysponowały wykształceniem policealnym - różnica prawie 2 pkt. proc.

Paradoksalnie to w grupie mężczyzn, zazwyczaj dążących do osiągnięcia dobrej pozycji na rynku pracy i tradycyjnie do utrzymania statusu głównego żywiciela rodziny, udział wykształcenia średniego ogólnego (1 pkt proc.) i gimnazjalnego (2,7 pkt. proc.) jest większy. Z perspektywy formalnej można więc uznać ich za nieposiadających kwalifikacji zawodowych (tabela 4). Gdyby więc szukać potencjału do zwiększenia kształcenia zawodowego, to leży on bardziej wśród mężczyzn niż wśród kobiet. Zwłaszcza że jest tu mowa o młodym pokoleniu. Udział osób w wieku 25-34 lata mających wykształcenie średnie ogólnokształcące jest znacznie wyższy niż w populacji ogółem, co może być wyrazem nasilających się nietrafionych, bo nieprowadzących do uzyskania kwalifikacji w żadnym zawodzie, decyzji edukacyjnych. Z uwagi na wiek tych osób nie można jednak wykluczyć, że w przyszłości podejmą one kształcenie uzupełniające. Nie zmienia to jednak faktu, że zwiększył się udział średniego kształcenia ogólnego, "ponadwymiarowego" w stosunku do dalszych możliwości kształcenia, niezapewniającego przygotowania zawodowego, szczególnie wśród młodzieży płci męskiej. 
Tabela 4. Struktura wykształcenia kobiet i mężczyzn w wieku 25-34 lata w 2017 r. (w \%)*

\begin{tabular}{c|c|c|c|c|c|c} 
płeć & wyższe & policealne & $\begin{array}{c}\text { średnie } \\
\text { zawodowe }\end{array}$ & $\begin{array}{c}\text { średnie } \\
\text { ogólne }\end{array}$ & $\begin{array}{c}\text { zasadnicze } \\
\text { zawodowe }\end{array}$ & $\begin{array}{c}\text { gimnazjalne } \\
\text { i niższe }\end{array}$ \\
\hline mężczyźni & 33,39 & 2,16 & 25,40 & 13,65 & 18,51 & 6,90 \\
\hline kobiety & 53,09 & 4,03 & 16,43 & 12,53 & 9,74 & 4,18
\end{tabular}

* Dane nie sumują się do $100 \%$ z powodu zaokrągleń.

Źródło: obliczenia własne na podstawie danych indywidualnych BAEL.

Niski udział wykształcenia zawodowego kobiet jest wynikiem bardzo wysokiej redukcji kształcenia się przez nie w szkołach zawodowych (w mniejszym stopniu w średnich i w bardzo wysokim - w zasadniczych). Spadek udziału tak wykształconych kobiet w wieku 25-34 lata wyniósł, odpowiednio, 26,3\% i 61,8\% (wykres 4b). Wśród młodych mężczyzn nie wystąpiło tak gwałtowne załamanie kształcenia zawodowego. Po pierwsze, udział mężczyzn w wieku 25-34 lata z wykształceniem średnim zawodowym był w 2017 r. nawet minimalnie wyższy od ich udziału z 2004 r. Po drugie, spadek udziału młodych mężczyzn z wykształceniem zawodowym zasadniczym, choć duży, pozostawał jednak mniejszy niż spadek udziału młodych kobiet z takim samym wykształceniem wyniósł 50,9\% (wykres 4a). A więc ogólne zmniejszenie udziału osób z wykształceniem zasadniczym w mniejszym stopniu wynikało z zachowań edukacyjnych mężczyzn niż kobiet. 
Wykres 4a. Zmiana struktury wykształcenia mężczyzn w wieku 25-34 lata w okresie 2004-2017

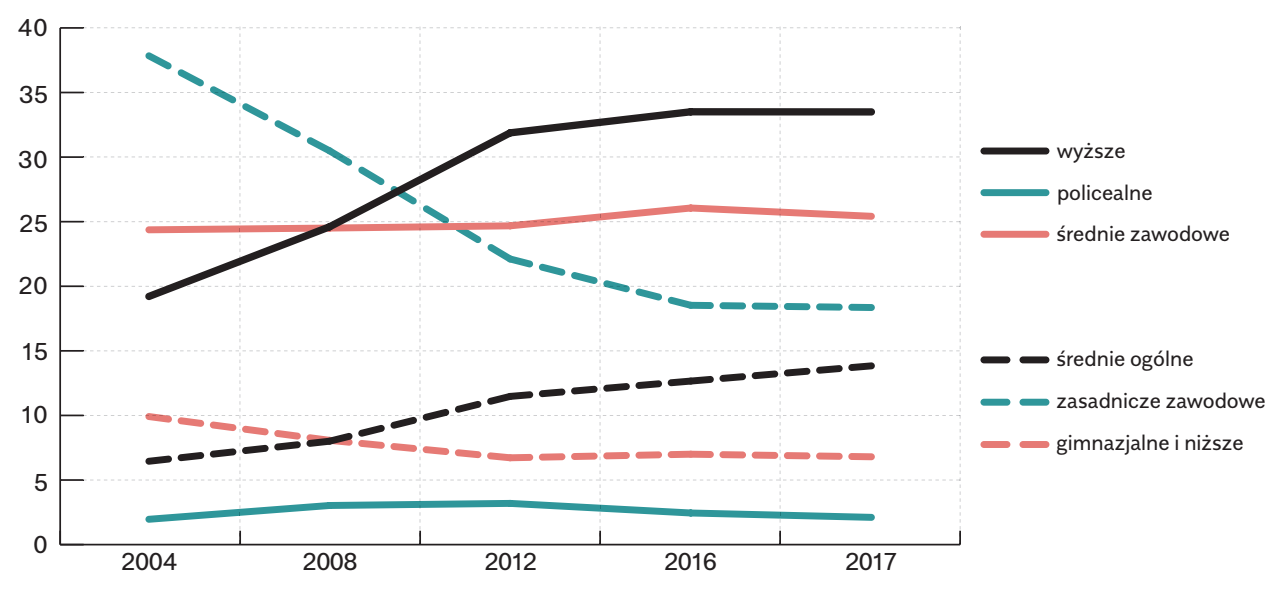

Wykres 4b. Zmiana struktury wykształcenia kobiet w wieku 25-34 lata w okresie 2004-2017

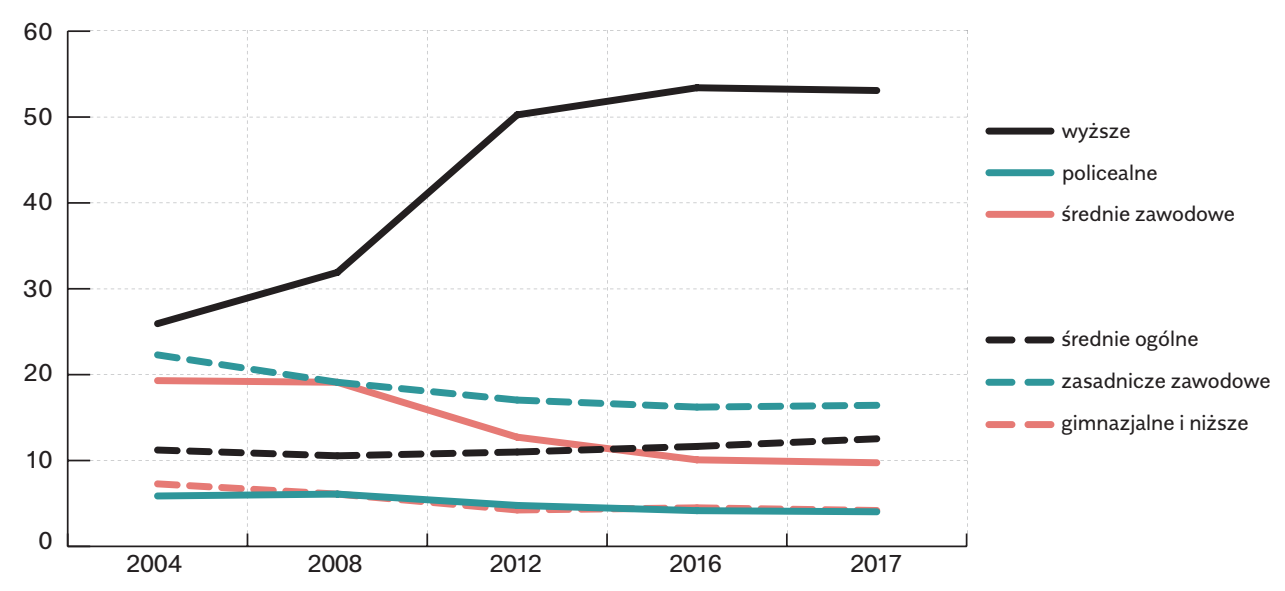

Źródło: obliczenia własne na podstawie danych indywidualnych BAEL.

Przez cały okres od wstąpienia Polski do UE, zarówno wśród kobiet, jak i mężczyzn, udział osób z wykształceniem wyższym i średnim ogólnym zwiększał się, zaś z zasadniczym zawodowym i gimnazjalnym lub 
niższym zmniejszał się. Dochodziło zatem do swoistej pokoleniowej wymiany wykształcenia relatywnie niskiego na stosunkowo najwyższe. Przy tym dynamika zmiany pokoleniowej w zakresie wyższego wykształcenia wydaje się słabnąć - relacje udziału osób z tym wykształceniem w najmłodszej generacji są wprawdzie ciągle wyższe niż w populacji ogółem, ale dla mężczyzn jej wielkość wynosiła w 2017 r. tylko 1,36, gdy jeszcze 5 lat wcześniej 1,55 (dla kobiet zaś w 2017 r. było to 1,49 , natomiast 5 lat wcześniej-1,74). Świadczy to o tym, że nowe pokolenia w coraz mniejszym stopniu wpływają na zwiększenie udziałów osób z wyższym wykształceniem w populacji ogółem. Z kolei dynamika spadku udziałów osób z wykształceniem zasadniczym zawodowym ustabilizowała się wśród mężczyzn dopiero w ostatnich dwóch latach i to na bardzo wysokim poziomie, co znaczy, że proces redukcji liczby mężczyzn z tym wykształceniem ciągle trwa. Wśród kobiet wręcz eskaluje. W każdej kolejnej grupie młodych kobiet udział posiadających wykształcenie zasadnicze jest coraz niższy (tabela 4).

Tabela 4. Stosunek udziału mężczyzn i kobiet o danym wykształceniu w wieku 25-34 lata do udziału mężczyzn i kobiet o danym wykształceniu w wieku 25-64 lata

\begin{tabular}{|c|c|c|c|c|c|c|}
\hline rok & wyższe & policealne & $\begin{array}{c}\text { średnie } \\
\text { zawodowe }\end{array}$ & $\begin{array}{l}\text { średnie } \\
\text { ogólne }\end{array}$ & $\begin{array}{l}\text { zasadnicze } \\
\text { zawodowe }\end{array}$ & $\begin{array}{c}\text { gimnazjalne } \\
\text { i niższe }\end{array}$ \\
\hline \multicolumn{7}{|c|}{ mężczyźni } \\
\hline 2004 & 1,356 & 1,312 & 1,063 & 1,491 & 0,904 & 0,653 \\
\hline 2008 & 1,542 & 1,529 & 1,034 & 1,667 & 0,751 & 0,666 \\
\hline 2012 & 1,551 & 1,404 & 1,053 & 1,865 & 0,592 & 0,670 \\
\hline 2016 & 1,421 & 1,303 & 1,067 & 1,896 & 0,534 & 0,806 \\
\hline 2017 & 1,360 & 1,146 & 1,062 & 1,933 & 0,534 & 0,865 \\
\hline \multicolumn{7}{|c|}{ kobiety } \\
\hline 2004 & 1,596 & 1,080 & 0,959 & 1,048 & 0,980 & 0,425 \\
\hline 2008 & 1,715 & 1,081 & 0,850 & 1,017 & 0,750 & 0,465 \\
\hline 2012 & 1,741 & 0,912 & 0,780 & 1,079 & 0,538 & 0,415 \\
\hline 2016 & 1,556 & 0,853 & 0,768 & 1,191 & 0,467 & 0,540 \\
\hline 2017 & 1,489 & 0,820 & 0,785 & 1,278 & 0,461 & 0,552 \\
\hline
\end{tabular}


Mniej jednoznaczne procesy dokonywały się w obrębie wykształcenia zawodowego średniego. Młodsze roczniki (25-34 lata) mężczyzn cechowały się większym udziałem tego wykształcenia niż populacja ogółem. Wśród młodych kobiet zaś sytuacja była odwrotna i w obserwowanym okresie wręcz nasilała się.

\section{Rozmieszczenie zasobów $\mathrm{z}$ wykształceniem zawodowym}

Osoby z wykształceniem zawodowym lokują się głównie w mniejszych ośrodkach. W dużych, liczących ponad 100 tys. mieszkańców, dominują osoby z wykształceniem wyższym. W największych jednostkach osiedleńczych udział osób z wykształceniem średnim zawodowym wynosił 19,6\% (2,8 pkt. proc. poniżej średniej ogólnokrajowej), a osób z wykształceniem zasadniczym zawodowym - 16,5\% (czyli aż o 11,4 pkt. proc. poniżej średniej ogólnokrajowej). Na przeciwległym biegunie znalazła się wieś z 22,8\% osób z wykształceniem średnim zawodowym, niemalże dokładnie na poziomie średniej ogólnopolskiej, oraz z $36,8 \%$ osób z wykształceniem zasadniczym (dominująca grupa wykształcenia na wsi), tj. aż o 9 pkt. proc. powyżej średniego udziału w skali kraju (wykres 5).

Wykres 5. Struktura wykształcenia ludności w wieku 25-64 lata w 2017 r.

w wyodrębnionych typach jednostek zamieszkania (w \%)

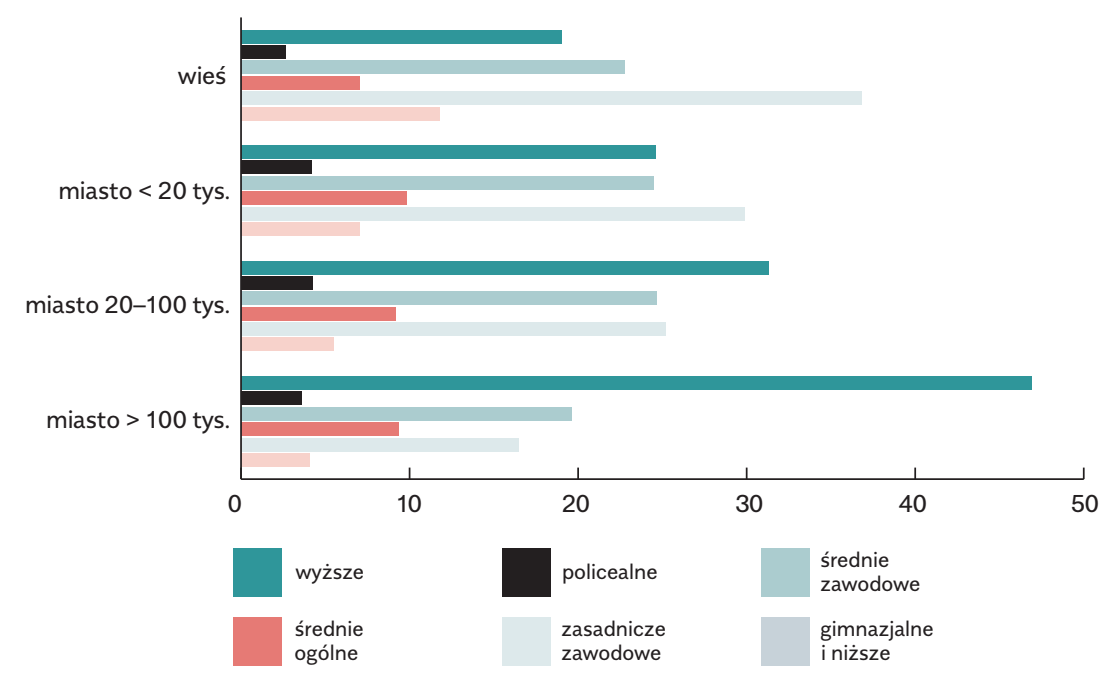

Źródło: obliczenia własne na podstawie danych indywidualnych BAEL. 
Im mniejszy ośrodek, tym udział osób posiadających wykształcenie zasadnicze był większy. Jednocześnie udział osób dysponujących średnim wykształceniem zawodowym nie różnił się tak bardzo między zróżnicowanymi pod względem wielkości miejscami zamieszkania. Generalnie wykształcenie średnie zawodowe i ogólnokształcące były reprezentowane z podobną częstotliwością na terenie różnych jednostek osiedleńczych. Natomiast wykształcenie wyższe i najniższe oraz zasadnicze zawodowe były zdecydowanie nierówno rozmieszczone.

Tendencje te nie zmieniały się znacząco $w$ młodym pokoleniu. Jednak wśród osób w wieku 25-34 lata w stosunku do całej populacji w wieku 25-64 lata bardziej zróżnicowało się rozmieszczenie osób z wykształceniem średnim zawodowym i jeszcze bardziej uwypukliła się zależność, że im mniejszy ośrodek, tym takich osób jest więcej. Podobnie były rozmieszczone osoby posiadające wykształcenie zasadnicze zawodowe (wykres 6).

Wykres 6. Struktura wykształcenia ludności w wieku 25-34 lata w 2017 r.

w wyodrębnionych typach jednostek zamieszkania (w \%)*

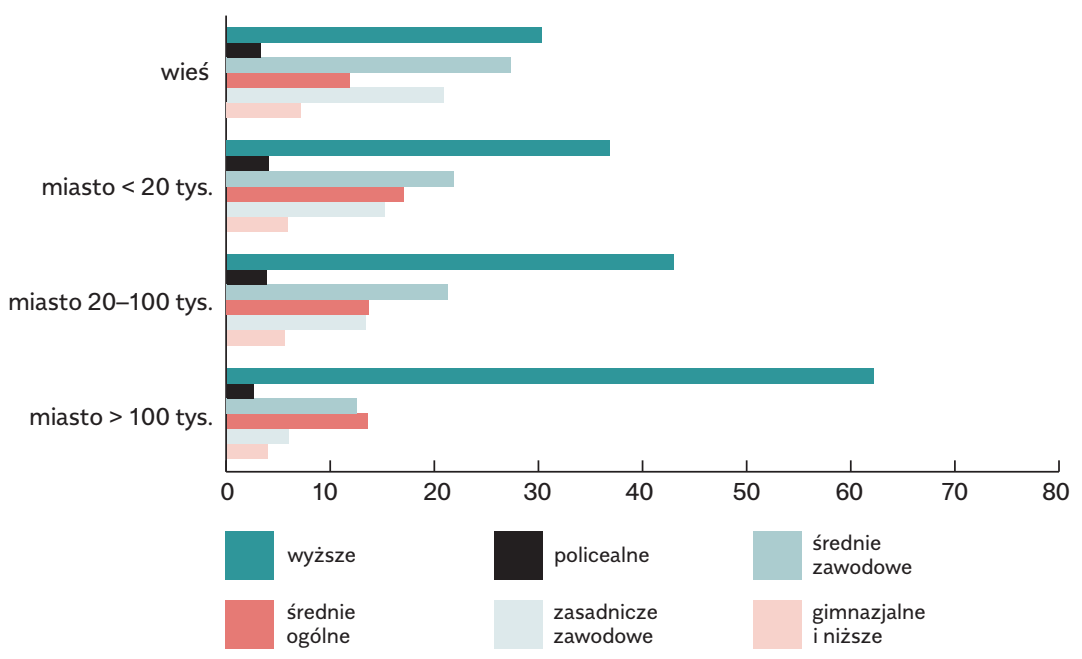

Źródło: obliczenia własne na podstawie danych indywidualnych BAEL. 
Zarazem to właśnie na wsi dokonał się największy awans edukacyjny - w 2017 r. udział osób w wieku 25-34 lata z wyższym wykształceniem był tam 2,7-krotnie wyższy niż w 2004 r. (podobnie w populacji 25-64 lata). W dużych, ponad stutysięcznych, miastach analogiczne relacje wynosiły 1,64 i 1,75 (tabela 5). Na wsi przybyło wiele osób z wykształceniem średnim zawodowym, natomiast w miastach (i to różnej wielkości) ich ubywało. Zatem fakt, że udział wykształcenia średniego zawodowego w strukturze wykształcenia ludności nie zmieniał się gwałtownie, wynikał z przeciwstawnych tendencji - zmniejszania tego udziału w miastach i zwiększania na wsi. Przy znacznym popycie na te kwalifikacje, jednak głównie na terenach miejskich, i barierach w mobilności może to rodzić problemy alokacyjne. Podobnie działo się z wykształceniem zasadniczym zawodowym, którego udział spadał we wszystkich typach jednostek osiedleńczych, jednak najwolniej na wsi. Powoduje to, że przede wszystkim tam są ulokowane zasoby osób z tym wykształceniem.

Tabela 5. Stosunek udziału osób o danym wykształceniu w 2017 r. do udziału osób o danym wykształceniu w 2004 r. według typów miejsca zamieszkania

\begin{tabular}{|c|c|c|c|c|c|c|}
\hline $\begin{array}{l}\text { typ jednostki } \\
\text { zamieszkania }\end{array}$ & wyższe & policealne & $\begin{array}{c}\text { średnie } \\
\text { zawodowe }\end{array}$ & $\begin{array}{l}\text { średnie } \\
\text { ogólne }\end{array}$ & $\begin{array}{l}\text { zasadnicze } \\
\text { zawodowe }\end{array}$ & $\begin{array}{c}\text { gimnazjalne } \\
\text { i niższe }\end{array}$ \\
\hline \multicolumn{7}{|c|}{ wiek 25-64 lata } \\
\hline wieś & 2,74 & 1,18 & 1,25 & 1,58 & 0,87 & 0,46 \\
\hline miasto $<20$ tys. & 1,90 & 0,99 & 0,96 & 1,11 & 0,87 & 0,50 \\
\hline $\begin{array}{l}\text { miasto } 20-100 \\
\text { tys. }\end{array}$ & 1,83 & 0,98 & 0,89 & 1,03 & 0,81 & 0,50 \\
\hline miasto $>100$ tys. & 1,75 & 0,85 & 0,78 & 0,94 & 0,65 & 0,47 \\
\hline \multicolumn{7}{|c|}{ wiek 25-34 lata } \\
\hline wieś & 2,70 & 0,97 & 1,25 & 1,97 & 0,46 & 0,56 \\
\hline miasto $<20$ tys. & 1,75 & 0,81 & 0,81 & 1,85 & 0,50 & 0,69 \\
\hline $\begin{array}{l}\text { miasto } 20-100 \\
\text { tys. }\end{array}$ & 1,68 & 0,77 & 0,78 & 1,38 & 0,49 & 0,92 \\
\hline miasto $>100$ tys. & 1,64 & 0,61 & 0,58 & 1,16 & 0,30 & 0,68 \\
\hline
\end{tabular}


Charakterystyczne jest też to, że we wszystkich typach jednostek osiedleńczych dochodziło do zwiększenia udziałów osób w wieku 25-34 lata z wykształceniem ogólnym, przy czym największą dynamiką zjawisko to odznaczało się na wsi. Musi to rodzić problemy z zatrudnieniem takich osób. Ograniczenie tego przyrostu przez silniejszą niż dotąd zachętę do podejmowania nauki w szkołach zawodowych wydaje się zatem uzasadnione.

\section{Kształcenie w szkołach ponadgimnazjalnych}

Struktura kształcenia jest nieadekwatna do obserwowanego, deklarowanego jako nieobsadzone miejsca pracy, popytu na pracę. Mało jest zwłaszcza uczniów w szkołach zasadniczych zawodowych, problem narastającego deficytu robotników wykwalifikowanych przynajmniej w części musi być tego następstwem. O ile w roku szkolnym 2016/2017 uczniów techników było nieco więcej niż uczniów liceów (43,6\% vs $41,8 \%$ ), o tyle już absolwentów było zdecydowanie mniej $(34,0 \%$ vs $49,6 \%)$. Udział absolwentów odpowiada w przybliżeniu udziałowi ofert pracy dla techników i średniego personelu biurowego, ale gdyby uwzględnić jeszcze oferty dla sprzedawców i pracowników usług, byłby zdecydowanie za mały. Udział absolwentów szkół zasadniczych zawodowych w populacji absolwentów szkół ponadgimnazjalnych wyniósł tylko $15,8 \%$, a to jest zdecydowanie zbyt mało w porównaniu do udziału stanowisk wymagających tych kwalifikacji w niezaspokojonym popycie na pracę. Bez trudu można dostrzec, że najbardziej poszukiwana grupa pracowników, tj. robotnicy wykwalifikowani i operatorzy maszyn i urządzeń, jest najmniej licznie reprezentowana wśród absolwentów i uczniów szkół ponadgimnazjalnych: wśród wolnych miejsc pracy $67,4 \%$ stanowią miejsca dla nich przeznaczone, a wśród absolwentów szkół ponadgimnazjalnych dla młodzieży takich osób jest tylko 15,8\%. Nawet jeśli populacja młodzieży wchodzącej na rynek pracy liczebnie równałaby się populacji odchodzącej z tego rynku na renty i emerytury, deficyt w grupie robotników kwalifikowanych oraz operatorów maszyn i urządzeń, a także na niektórych stanowiskach w handlu i usługach byłby oczywisty. Największe ilościowe niedopasowanie strukturalne edukacji zawodowej dotyczy właśnie tego poziomu wykształcenia. 
Wykres 7. Struktura kształcenia ponadgimnazjalnego 2016/2017 (w tys.)

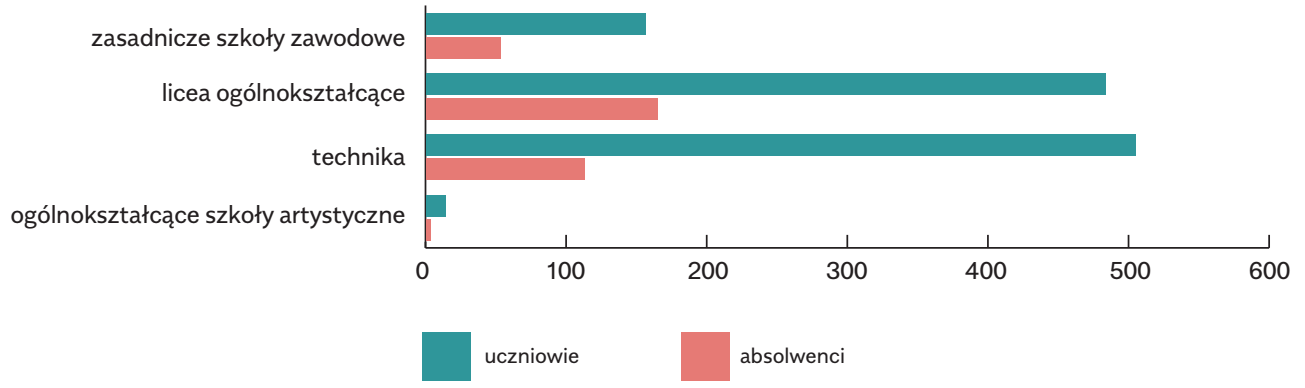

Źródło: obliczenia własne na podstawie Oświata i wychowanie... 2017.

Dość trafnie zauważono, że warunkiem rozwoju kształcenia zawodowego jest uzyskanie efektu popytowego nie tylko na rynku pracy, ale i w samym szkolnictwie ponadgimnazjalnym - liczba absolwentów szkół zawodowych nie wzrośnie, jeśli liczniej nie pojawią się chętni do kształcenia w szkołach zawodowych, w tym zasadniczych. Stąd nieodmiennie od wielu lat prowadzone są działania promocyjne szkolnictwa zawodowego. Nie wystarczy to jednak - jak się wydaje - bez istotnej zmiany proporcji wynagrodzeń, która uczyniłaby pracę na stanowiskach robotniczych oraz operatorów maszyn i urządzeń bardziej atrakcyjną (por. rozdział 3).

\section{Struktura kwalifikacji osób z wykształceniem zawodowym}

Zdecydowana większość osób z wykształceniem zawodowym uzyskała je $w$ dziedzinach związanych z techniką, przemysłem lub budownictwem. Według danych BAEL za 2017 r. było to aż $71,7 \%$ osób z wykształceniem zasadniczym zawodowym oraz $49,8 \%$ z wykształceniem średnim zawodowym. W populacji ogółem osób wykształconych w tych dziedzinach było wyraźnie mniej - tylko 35,7\%. Struktura wykształcenia młodych osób w wieku 25-34 lata była zbliżona do struktury grupy w wieku 25-64 lata, co wskazywałoby na pewną stabilność dziedzinowej struktury wykształcenia. $Z$ drugiej jednak strony można dostrzec, że technika, przemysł i budownictwo jako dziedziny kształcenia zawodowego w młodszym pokoleniu trochę traciły na popularności. Wśród młodych tego rodzaju wykształceniem mogło pochwalić się "tylko" 63,1\% osób mających wykształcenie zasadnicze i $42,2 \%$ z wykształceniem średnim. 
Według danych za 2017 r. ogół osób w wieku 25-64 lata z wykształceniem zasadniczym dość często dysponował też przygotowaniem do pracy w usługach -10,3\%, w dziedzinie biznesu i prawa (chodzi głównie o pracę w handlu) $-8,9 \%$, a także w rolnictwie - 8,3\%. Wśród osób młodszych, tj. w wieku 25-34 lata, waga rolnictwa zdecydowanie zmalała - do $2,7 \%$, a wzrosła - usług - do 19,8\% oraz biznesu i prawa-do 13,7\%. Niemniej wykształcenie absolwentów szkół zasadniczych przygotowywało głównie do zajęć związanych z techniką, przemysłem i budownictwem. Znaczenie pozostałych dziedzin wykształcenia pozostawało dużo mniejsze (wykres 8). Jeśli zauważa się zatem deficyt pracowników z wykształceniem zasadniczym zawodowym, to dotyczy on głównie robotników dla przemysłu i budownictwa, a w mniejszym stopniu dla usług i handlu.

Wykres 8. Dziedzinowa struktura zasadniczego zawodowego

wykształcenia ludności w 2017 r. (w \%)

25-64 lata

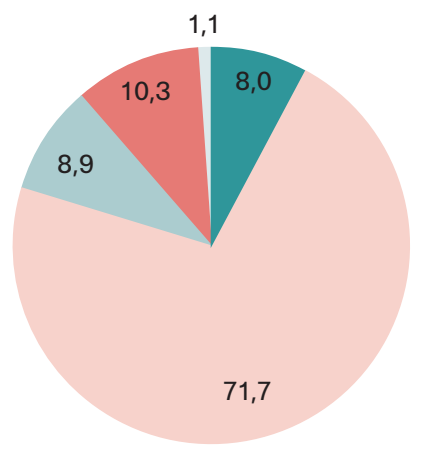

biznes, prawo

technika, technika,
przemysł

rolnictwo

usługi

pozostałe
25-34 lata

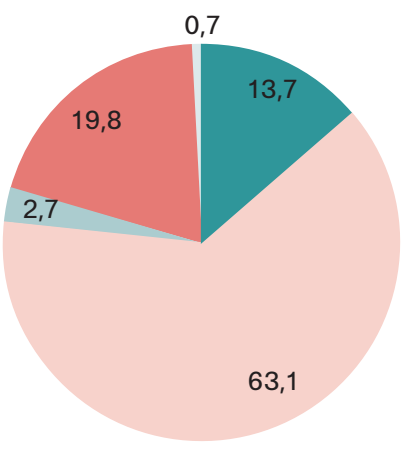

Źródło: obliczenia własne na podstawie danych indywidualnych BAEL.

Z kolei badania populacji z wykształceniem średnim zawodowym wskazały więcej dziedzin, do których absolwenci uzyskali przygotowanie zawodowe. Poza techniką, przemysłem i budownictwem duży udział w strukturze wykształcenia miało przygotowanie do pracy w usługach i biznesie. Kierunki te zyskiwały na popularności w młodszej generacji (w $2017 \mathrm{r}$. w populacji 25-34 lata, było to, odpowiednio, 16,6\% i 12,6\%). Prawdziwą ekspansję przeżywało kształcenie teleinformatyczne. Natomiast, o ile wśród ogółu osób z wykształceniem średnim za- 
wodowym liczne były grupy absolwentów wykształconych w dziedzinach społecznej i związanej ze zdrowiem, to w młodym pokoleniu wykształcenie w nich stawało się coraz rzadsze, podobnie zmieniało się kształcenie w zakresie rolnictwa (wykres 9). Modyfikacja klasyfikacji dziedzin kształcenia w Badaniu Aktywności Ekonomicznej Ludności GUS uniemożliwia pełną identyfikację zmian, jakie zachodziły w tym zakresie w wykształceniu zawodowym. Niemniej można zauważyć, że wśród młodszych osób legitymujących się wykształceniem średnim zawodowym udział osób wykształconych w dziedzinie techniki, przemysłu i budownictwa zmalał o 7,6 pkt. proc., a wśród legitymujących się wykształceniem zasadniczym o prawie 8,6 pkt. proc., choć nadal w tej dziedzinie kształci się przeważająca część młodzieży uczęszczającej do szkół zawodowych. Zdecydowanie zaś w młodszym pokoleniu zwiększył się udział wykształconych w dziedzinie biznesu (i prawa) - w przypadku legitymujących się wykształceniem średnim wykształceniem zawodowym o 3 pkt. proc., zaś wśród posiadających wykształcenie zasadnicze - o 5,7 pkt. proc. Dynamicznie wzrastał również udział przygotowanych do pracy w usługach - wśród posiadających wykształcenie średnie o 8 pkt. proc, a wśród posiadających zasadnicze nawet o 9,5 pkt. proc. W przeciwnym kierunku podążają zmiany odnoszące się do wykształcenia rolniczego - na poziomie średnim udział tak wykształconych spadł o 3,2 pkt. proc., a na poziomie zasadniczym nawet o ponad 6,2 pkt. proc. (tabela 6).

Wykres 9. Dziedzinowa struktura średniego zawodowego

wykształcenia ludności w 2017 r. (w \%)

\section{5-64 lata}

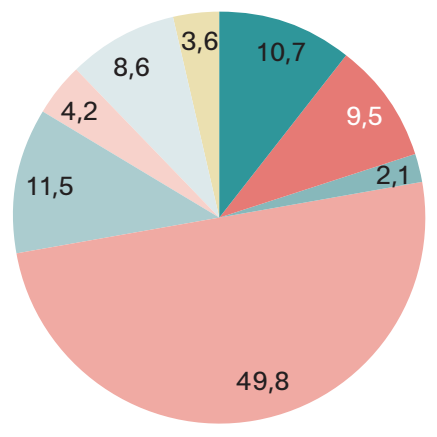

25-34 lata

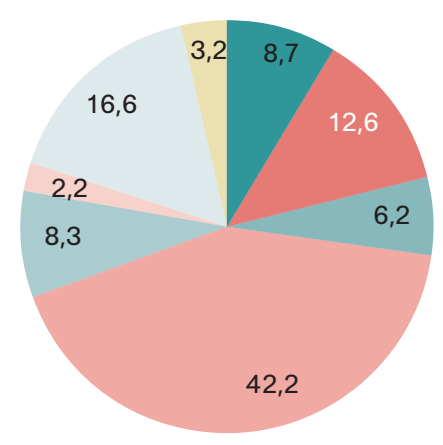

Źródło: obliczenia własne na podstawie danych indywidualnych BAEL 
Wydaje się, że opisane zmiany mają związek - choć niebezpośredni - ze zmianami popytu na pracę i struktury zatrudnienia. Stosunkowo więcej osób podejmuje bowiem pracę $\mathrm{w}$ szeroko rozumianym biznesie (np. rachunkowość, handel), a coraz mniej w rolnictwie. Rozwijało się zatrudnienie w usługach, malało w przemyśle. Zmieniał się świat informacji - odzwierciedliło się to $w$ zmianach kształcenia teleinformatycznego. Zmniejszenie częstotliwości kształcenia zawodowego związanego z opieką zdrowotną wynika zaś z wymagań formalnych zatrudnienia w zakresie zdrowia. Dawniej personel pomocniczy dla ochrony zdrowia był kształcony głównie w szkołach średnich (pielęgniarki, technicy medyczni, pomoce dentystyczne, sekretarki medyczne), aktualnie wymaga się od niego głównie wykształcenia wyższego, co w naturalny sposób musiało odbić się na ograniczeniu kształcenia w tej dziedzinie na poziomie średnim.

Tabela 6. Struktura wykształcenia zawodowego ludności według dziedzin w 2017 r. (w \%)*

\begin{tabular}{|c|c|c|c|c|c|c|}
\hline \multirow[b]{3}{*}{$\begin{array}{l}\text { dziedzina } \\
\text { wykształcenia }\end{array}$} & \multicolumn{3}{|c|}{ ludność w wieku 25-64 lata } & \multicolumn{3}{|c|}{ ludność w wieku 25-34 lata } \\
\hline & \multicolumn{6}{|c|}{ wykształcenie } \\
\hline & $\begin{array}{c}\text { średnie } \\
\text { zawodowe }\end{array}$ & $\begin{array}{l}\text { zasadnicze } \\
\text { zawodowe }\end{array}$ & ogółem & $\begin{array}{c}\text { średnie } \\
\text { zawodowe }\end{array}$ & $\begin{array}{l}\text { zasadnicze } \\
\text { zawodowe }\end{array}$ & ogółem \\
\hline ogólne & 0,7 & 0,0 & 16,2 & 0,9 & 0,0 & 18,5 \\
\hline pedagogika & 0,2 & 0,0 & 4,9 & 0,0 & 0,0 & 5,6 \\
\hline humanistyka & 0,8 & 0,4 & 2,5 & 0,8 & 0,2 & 3,3 \\
\hline społeczne & 10,7 & 0,1 & 8,0 & 8,7 & 0,0 & 8,8 \\
\hline biznes, prawo & 9,5 & 8,0 & 11,5 & 12,6 & 13,7 & 15,7 \\
\hline $\begin{array}{l}\text { przyrodnicze, } \\
\text { matematyka }\end{array}$ & 1,5 & 0,1 & 2,1 & 1,1 & 0,0 & 2,8 \\
\hline teleinformatyka & 2,1 & 0,0 & 2,0 & 6,2 & 0,0 & 4,0 \\
\hline $\begin{array}{l}\text { technika, przemysł, } \\
\text { budownictwo }\end{array}$ & 49,8 & 71,7 & 35,7 & 42,2 & 63,1 & 23,6 \\
\hline rolnictwo & 11,5 & 8,9 & 5,9 & 8,3 & 2,7 & 3,0 \\
\hline zdrowie & 4,2 & 0,1 & 4,3 & 2,2 & 0,0 & 4,6 \\
\hline usługi & 8,6 & 10,3 & 6,5 & 16,6 & 19,8 & 9,7 \\
\hline nie wiem & 0,3 & 0,3 & 0,4 & 0,3 & 0,4 & 0,5 \\
\hline
\end{tabular}

* Dane nie sumują się do $100 \%$ z powodu zaokrągleń do jednego miejsca po przecinku.

Źródło: obliczenia własne na podstawie danych indywidualnych BAEL. 
Choć zmiana systemu klasyfikacji dziedzin wykształcenia uniemożliwia pełne porównanie w czasie, to jednak wskazuje na to, że w ostatnich latach występował systematyczny proces zawężania dziedzinowych wyborów w kształceniu zawodowym. Ubyło wykształconych na poziomie średnim w dziedzinach społecznej, zdrowia, rolnictwa. Z jednej strony mamy więc do czynienia z pośrednim oddziaływaniem popytu na pracę powodującym eliminację opłacalności uczenia się $w$ dziedzinach, w których ten popyt spadł, co wydaje się ze wszech miar zjawiskiem korzystnym. Z drugiej zaś strony ubocznym efektem tego procesu jest ograniczenie szerokości wyboru zawodowego dla tych, którzy nie chcieliby kontynuować nauki aż do studiów wyższych.

\section{Rynek pracy osób z wykształceniem zawodowym}

Najbardziej popularne wskaźniki rynku pracy pokazują, że od 2004 r. systematycznie poprawiała się sytuacja na rynku pracy - stopniowo rosły aktywność zawodowa (o prawie 4 pkt. proc.) i zatrudnienie (aż prawie o 12,5 pkt. proc.), malało bezrobocie (też o prawie 12 pkt. proc., tabela 7). Tylko po kryzysie w 2008 r. stopa bezrobocia ogółem w populacji 25-64 lata przejściowo wzrosła, aby jednak spaść w końcowym okresie obserwacji do rekordowo niskiego poziomu $4,1 \%$. 
Tabela 7. Wskaźniki rynku pracy w okresie 2004-2017

dla populacji w wieku 25-64 lata (w \%)

\begin{tabular}{|c|c|c|c|}
\hline rok & $\begin{array}{c}\text { współczynnik aktywności } \\
\text { zawodowej }\end{array}$ & wskaźnik zatrudnienia & stopa bezrobocia \\
\hline & \multicolumn{3}{|c|}{ populacja ogółem } \\
\hline 2004 & 72,74 & 60,94 & 16,23 \\
\hline 2008 & 72,19 & 67,80 & 6,08 \\
\hline 2012 & 74,37 & 67,91 & 8,69 \\
\hline 2016 & 76,12 & 72,08 & 5,31 \\
\hline \multirow[t]{2}{*}{2017} & 76,67 & 73,48 & 4,17 \\
\hline & \multicolumn{3}{|c|}{ populacja osób z wykształceniem średnim zawodowym } \\
\hline 2004 & 77,03 & 66,52 & 13,64 \\
\hline 2008 & 74,95 & 70,98 & 5,30 \\
\hline 2012 & 76,91 & 71,57 & 6,94 \\
\hline 2016 & 77,80 & 74,35 & 4,44 \\
\hline \multirow[t]{2}{*}{2017} & 77,99 & 75,27 & 3,50 \\
\hline & \multicolumn{3}{|c|}{ populacja osób z wykształceniem zasadniczym zawodowym } \\
\hline 2004 & 73,41 & 58,33 & 20,53 \\
\hline 2008 & 70,56 & 65,53 & 7,12 \\
\hline 2012 & 69,86 & 62,20 & 10,96 \\
\hline 2016 & 70,01 & 65,17 & 6,91 \\
\hline 2017 & 70,24 & 66,19 & 5,76 \\
\hline
\end{tabular}

Źródło: obliczenia własne na podstawie danych indywidualnych BAEL.

Opisane tendencje nie odnosiły się jednak w pełni do sytuacji osób z wykształceniem zawodowym. Po pierwsze, stopa aktywności zawodowej osób z wykształceniem średnim zawodowym utrzymywała się na dość zbliżonym poziomie w całym okresie obserwacji, z przejściowym tylko spadkiem w okresie pokryzysowym. Aktywność zawodowa osób z wykształceniem zasadniczym spadła zaś w długiej perspektywie (o nieco ponad 3 pkt. proc.). Po drugie, choć też odnotowano zwiększenie wskaźnika zatrudnienia w grupie posiadającej wykształcenie średnie zawodowe i zasadnicze zawodowe, to jednak w mniejszej skali (odpowiednio, o około 9 pkt. proc. i 8 pkt. proc.) niż przeciętnie. Po trzecie, bezrobocie wśród dysponujących średnim wykształceniem zawodowym utrzymywało się poniżej poziomu dla całej populacji, ale 
wśród mających wykształcenie zasadnicze pozostawało stale większe. Te trendy stoją w wyraźnej opozycji do niezrealizowanego popytu na pracę (wykresy 1 i 2), bowiem pracodawcy z coraz większym natężeniem poszukują pracowników z wykształceniem zawodowym na poziomie zasadniczym i średnim. Jednocześnie znalezienie pracy wciąż było i nadal jest - zwłaszcza dla posiadających wykształcenie zasadnicze - większym problemem niż dla pozostałych osób.

Ponieważ osoby z wykształceniem zawodowym stanowią istotną część rynku pracy w Polsce, to sposób, w jaki kształtują się ich losy na tym rynku, rzutuje na ogólną sytuację gospodarczą i społeczną. W 2017 r. aż 47,8\% osób pracujących dysponowało wykształceniem zawodowym, mniej więcej w podobnej proporcji średnim lub zasadniczym, a jeszcze w 2004 r. było takich osób zdecydowanie więcej, bo $57,7 \%$. Przy czym ok. 3/5 z nich miało wykształcenie zasadnicze (tabela 8).

Tabela 8. Udział osób z wykształceniem zawodowym w populacji pracujących, bezrobotnych i biernych ogółem w 2004 i 2017 r. (w \%)

\begin{tabular}{l|c|c|c|c}
\multirow{2}{*}{$\begin{array}{l}\text { udział osób } \\
\text { w populacji }\end{array}$} & \multicolumn{2}{|c|}{ średnie zawodowe } & 2004 & 2017 \\
\cline { 2 - 4 } & 2004 & 2017 & 33,0 & 25,1 \\
\hline pracujących & 24,7 & 22,7 & 44,1 & 35,2 \\
\hline bezrobotnych & 20,1 & 18,9 & 33,7 & 35,5
\end{tabular}

Źródło: obliczenia własne na podstawie danych indywidualnych BAEL.

Zarazem, zarówno w 2017, jak i w 2004 r., udział osób z wykształceniem zasadniczym zawodowym wśród bezrobotnych przewyższał udział osób z tym wykształceniem wśród zatrudnionych, a także udział tej grupy w populacji (tabela 1). Pokazuje to, że osoby posiadające wykształcenie zasadnicze ponadprzeciętnie często stawały się bezrobotne. Wydaje się to zaskakujące w świetle zgłaszanego przez pracodawców dużego popytu na pracę - można przypuścić, że albo szczegółowe kwalifikacje bezrobotnych osób z wykształceniem zasadniczym zawodowym nie odpowiadały oczekiwaniom pracodawców, albo rozmieszczenie wolnych zasobów pracy osób z zasadniczym przygotowaniem zawodowym nie pokrywało się z terytorialnym rozkładem popytu 
na pracę. Innym powodem może być też to, że szczegółowe cechy, w tym związane z motywacjami do pracy, nie zachęcały do zatrudniania części osób z tym typem wykształcenia. Także wśród biernych udział osób z zasadniczym wykształceniem zawodowym przewyższał ich udział w populacji ogółem. Wszystko to razem wskazuje, że istnieje wyraźny problem z zatrudnialnością tej grupy osób, co może - przynajmniej w części - wyjaśniać znaczną niechęć młodzieży do podejmowania nauki w zasadniczych szkołach zawodowych. W dodatku jest to trudność, która cechuje się znaczną trwałością i nawet w okresie bardzo dobrej sytuacji na rynku pracy - jak np. w 2017 r. - nie znika (wykres 10). Braki na rynku pracy osób z wykształceniem zasadniczym to nie tylko kwestia niskiego zainteresowania młodych kształceniem w odpowiadających mu placówkach, ale też rezultat wysokiego poziomu bierności zawodowej tej grupy.

Tak negatywne nastawienie nie dotyczy osób wykształconych w średnich szkołach zawodowych. W świetle udziału osób z takim wykształceniem w rynku pracy wydaje się uzasadnione oczekiwanie, że ukończenie technikum zapewni przynajmniej z przeciętnym dla całej populacji lub nawet nieco większym prawdopodobieństwem możliwości pracy zawodowej (tabela 7, wykres 10).

Wykres 10. Struktura populacji ze względu na aktywność zawodową w 2017 r.

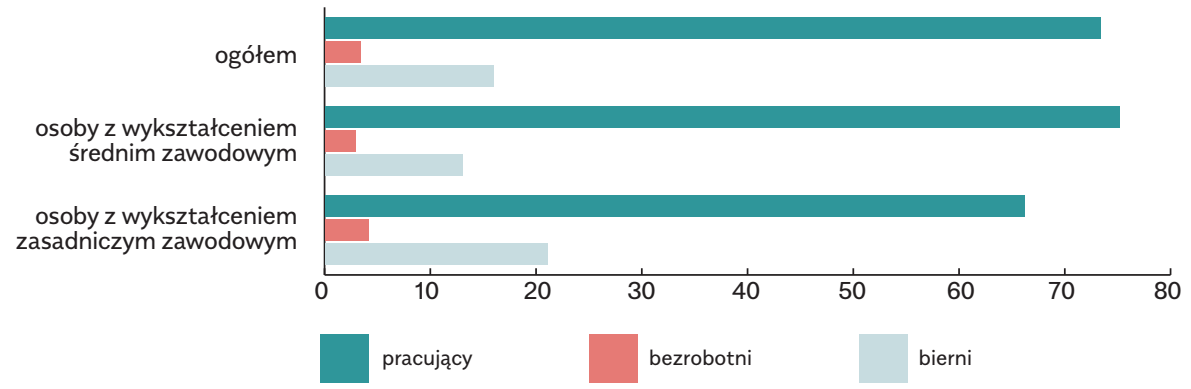

Źródło: obliczenia własne na podstawie danych indywidualnych BAEL.

W całym okresie obserwacji, tj. od 2004 do 2017 r., osoby z wykształceniem zasadniczym były ponadprzeciętnie często bezrobotne lub bierne, a osoby z wykształceniem średnim zawodowym ponadprze- 
ciętnie często pracowały (tabela 9). Nadto sytuacja osób z wykształceniem zasadniczym zawodowym - patrząc na ich relatywny udział wśród bezrobotnych - pogarszała się po 2008 r., co nie odpowiadało korzystnym zmianom zachodzącym wówczas na krajowym rynku pracy. Relatywny udział w bezrobociu osób z wykształceniem średnim zawodowym natomiast nie malał, co wskazuje, że grupa ta poprawiała swoją pozycję na rynku pracy.

Tabela 9. Stosunek udziału osób z wykształceniem średnim i zasadniczym zawodowym o danym statusie na rynku pracy do udziału osób o tym samym statusie w populacji ogółem

\begin{tabular}{l|c|c|c} 
rok & pracujący & bezrobotni & bierni \\
\hline 2004 & \multicolumn{2}{|c}{ średnie zawodowe } & 0,811 \\
\hline 2008 & 1,092 & 0,890 & 0,851 \\
\hline 2012 & 1,047 & 0,905 & 0,790 \\
\hline 2016 & 1,054 & 0,827 & 0,809 \\
\hline 2017 & 1,031 & 0,855 & 0,815 \\
\hline 2004 & 1,024 & 0,853 & 0,985 \\
\hline 2008 & \multicolumn{2}{|c|}{ zasadnicze zawodowe } \\
\hline 2012 & 0,957 & 1,277 & 1,076 \\
\hline 2016 & 0,967 & 1,145 & 1,216 \\
\hline 2017 & 0,916 & 1,186 & 1,288 \\
\hline
\end{tabular}

Źródło: obliczenia własne na podstawie danych indywidualnych BAEL.

Ogółem dość duży dystans dzieli osoby z wykształceniem średnim zawodowym od osób z wykształceniem zasadniczym w 2017 r. stopa aktywności zawodowej tych pierwszych o prawie 8 pkt. proc. przewyższała stopę aktywności tych drugich. Wiązało się to $z$ jeszcze większą luką w zatrudnieniu - wskaźnik zatrudnienia był dla posiadających wykształcenie średnie o ponad 9 pkt. proc. wyższy (tabele 7 i 9). O ile więc można uznać, że z perspektywy rynku pracy wykształcenie średnie zawodowe jest stosunkowo atrakcyjne, o tyle 
wykształcenie zasadnicze wiąże się z dużym ryzykiem niewykonywania pracy zarobkowej: zarówno bezrobocia, jak i bierności.

\section{Sytuacja młodej generacji z wyksztalceniem zawodowym}

Populacja osób młodych, w tym również dysponujących wykształceniem zawodowym, cechuje się wyraźnie większą aktywnością zawodową niż całość populacji w wieku produkcyjnym. Wyższe są wśród młodych również wskaźniki zatrudnienia i stopa bezrobocia (tabela 10).

Chociaż młode osoby z wykształceniem zasadniczym zawodowym cechuje mniejsza aktywność zawodowa niż młode osoby ze średnim wykształceniem zawodowym, to jednak w porównaniu z ogółem osób w wieku 25-64 lata posiadających wykształcenie zasadnicze młodzi są dużo bardziej aktywni - o 14-17\%. Napotykają też jednak na wyraźne trudności w podjęciu pracy, czego wyrazem jest stosunkowo wysokie bezrobocie. W tym wieku, 25-34 lata, mają już za sobą kilkuletni okres przebywania na rynku pracy, a co za tym idzie, nie znajdują się w sytuacji pierwszego wejścia na ten rynek bezpośrednio po ukończeniu szkoły, kiedy to bezrobocie jest szczególnie powszechne. Mimo to stopa bezrobocia tych osób okazuje się (w 2017 r.) wyższa aż o 51\% od stopy bezrobocia całej populacji z tym wykształceniem (wykres 11). Takie proporcje są charakterystyczne także dla absolwentów (Badanie aktywności zawodowej... 2008). 
Tabela 10. Wskaźniki rynku pracy w okresie 2004-2017 dla populacji w wieku 25-34 lata

\begin{tabular}{|c|c|c|c|}
\hline rok & $\begin{array}{l}\text { współczynnik aktywności } \\
\text { zawodowej }\end{array}$ & wskaźnik zatrudnienia & stopa bezrobocia \\
\hline & \multicolumn{3}{|c|}{ populacja ogółem } \\
\hline 2004 & 85,57 & 69,32 & 18,98 \\
\hline 2008 & 83,98 & 77,86 & 7,28 \\
\hline 2012 & 84,84 & 75,43 & 11,09 \\
\hline 2016 & 84,99 & 79,06 & 6,98 \\
\hline \multirow[t]{2}{*}{2017} & 84,02 & 79,55 & 5,32 \\
\hline & \multicolumn{3}{|c|}{ populacja osób z wykształceniem średnim zawodowym } \\
\hline 2004 & 87,00 & 72,04 & 17,19 \\
\hline 2008 & 84,37 & 79,31 & 5,99 \\
\hline 2012 & 86,33 & 77,87 & 9,80 \\
\hline 2016 & 87,78 & 82,38 & 6,15 \\
\hline \multirow[t]{2}{*}{2017} & 85,78 & 81,70 & 4,76 \\
\hline & \multicolumn{3}{|c|}{ populacja osób z wykształceniem zasadniczym zawodowym } \\
\hline 2004 & 84,98 & 65,26 & 23,20 \\
\hline 2008 & 81,89 & 74,68 & 8,81 \\
\hline 2012 & 81,49 & 68,92 & 15,43 \\
\hline 2016 & 79,93 & 71,57 & 10,45 \\
\hline 2017 & 79,81 & 72,89 & 8,68 \\
\hline
\end{tabular}

Źródło: obliczenia własne na podstawie danych indywidualnych BAEL.

Wydaje się to paradoksalne w świetle zgłaszanego popytu na pracę dla tej grupy i każe przypuszczać, że między młodymi a starszymi osobami z wykształceniem zasadniczym zawodowym istnieją duże różnice o charakterze strukturalnym, oddziałujące na niekorzyść młodych. Zdaje się, że ta tendencja wzmacniała się w całym badanym okresie, tj. od 2004 do 2017 r., kiedy to bezrobocie młodych osób z wykształceniem zasadniczym zawodowym wprawdzie też było wyższe niż w bezrobocie ogółu osób z tym wykształceniem w wieku produkcyjnym, jednak różnica między tymi populacjami była zdecydowanie mniejsza niż w pozostałych grupach wykształcenia. W 2017 r. było na odwrót. Polski rynek cechowała znacznie gorsza sytuacja osób młodych niż osób starszych, szczególnie w odniesieniu do posiadających wykształcenie zasadnicze zawodowe (wykres 11). Może to świadczyć o niedostatkach jakości kształ- 
cenia zawodowego, jego nieadekwatnej do popytu strukturze zawodowej, a także o rozmieszczeniu terytorialnym osób z tym wykształceniem niepasującym do rozmieszczenia odpowiednich dla nich miejsc pracy.

Wykres 11. Relacja podstawowych wskaźników rynku pracy dla osób z wykształceniem zawodowym w wieku 25-34 lata do wskaźników dla populacji w wieku 25-64 lata

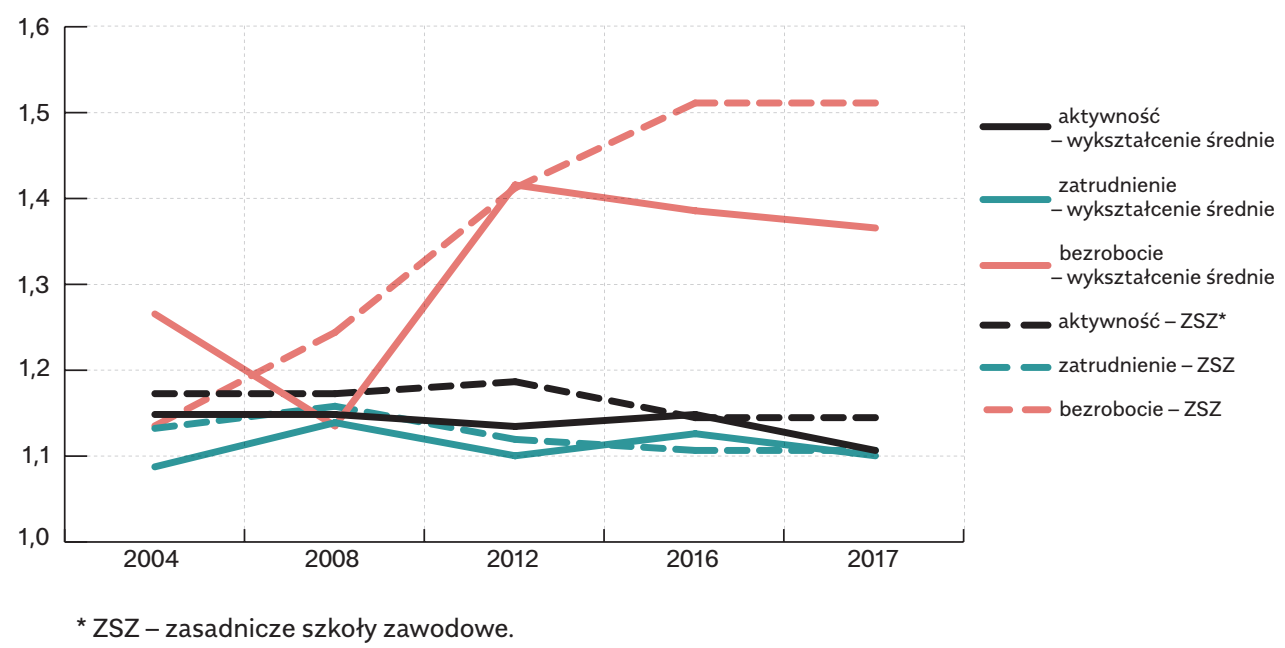

Źródło: obliczenia własne na podstawie danych indywidualnych BAEL.

Podobnie przedstawia się sytuacja dla osób ze średnim wykształceniem zawodowym, aczkolwiek $w$ ich przypadku różnica między stopą bezrobocia osób w wieku 25-34 lata w stosunku do osób 25-64 lata wynosi $36 \%$ i w ostatnim roku zmalała. To jednak jeszcze nie przesądza, że w kolejnych latach uda się zmniejszyć lukę pokoleniową w tym zakresie, choć istnieją wyraźne symptomy poprawy sytuacji i osób z tym wykształceniem, w tym także młodych.

\section{Młodzi na rynku pracy: kobiety vs mężczyźni}

Na rynku pracy sytuacja zarówno kobiet, jak i mężczyzn w wieku 25-34 lat z wykształceniem zawodowym dość systematycznie poprawiała się, wyjątek stanowił okres 2008-2012, kiedy w następstwie kryzysu zwiększyły się stopy bezrobocia i nieco spadły wskaźniki zatrudnienia osób obu płci, podobnie zresztą jak wśród ogółu ludności (tabela 11). Niemniej w 2017 r. aktywność zawodowa i zatrudnienie 
mężczyzn z wykształceniem średnim zawodowym były najwyższe w analizowanym okresie 14 lat, zaś stopa bezrobocia najniższa. Podobnie sytuacja wyglądała wśród mężczyzn z wykształceniem zasadniczym zawodowym, z tym że ich aktywność zawodowa była w 2004 r. wyższa niż w 2017 r., ale wówczas w dużym stopniu wyrażała się nieskutecznym poszukiwaniem pracy. Mniejszej o 1 pkt proc. stopie aktywności zawodowej towarzyszy dużo niższa stopa bezrobocia - niemal o 13 pkt. proc., co zasadniczo można uznać za poprawę sytuacji tej grupy. Młodzi mężczyźni z wykształceniem średnim zawodowym właściwie nie znają bezrobocia, a i bierność zawodowa stosunkowo rzadko ich dotyczy. Z kolei bezrobocie częściej dotyka młodych mężczyzn z wykształceniem zasadniczym - stopa bezrobocia wynosi dla nich 8,6\%.

Tabela 11. Wskaźniki rynku pracy w okresie 2004-2017

dla mężczyzn i kobiet w wieku 25-34 lata

\begin{tabular}{|c|c|c|c|c|c|c|}
\hline \multirow{2}{*}{ rok } & \multicolumn{3}{|c|}{ mężczyźni } & \multicolumn{3}{|c|}{ kobiety } \\
\hline & $\begin{array}{c}\text { współczynnik } \\
\text { aktywności } \\
\text { zawodowej }\end{array}$ & $\begin{array}{c}\text { wskaźnik } \\
\text { zatrudnienia }\end{array}$ & $\begin{array}{c}\text { stopa } \\
\text { bezrobocia }\end{array}$ & $\begin{array}{c}\text { współczynnik } \\
\text { aktywności } \\
\text { zawodowej }\end{array}$ & $\begin{array}{c}\text { wskaźnik } \\
\text { zatrudnienia }\end{array}$ & $\begin{array}{c}\text { stopa } \\
\text { bezrobocia }\end{array}$ \\
\hline & \multicolumn{6}{|c|}{ wszystkie poziomy wykształcenia } \\
\hline 2004 & 93,28 & 77,11 & 17,33 & 77,69 & 61,37 & 21,01 \\
\hline 2008 & 91,98 & 85,98 & 6,52 & 75,94 & 69,70 & 8,21 \\
\hline 2012 & 92,48 & 83,39 & 9,82 & 76,81 & 67,06 & 12,70 \\
\hline 2016 & 92,80 & 86,56 & 6,72 & 76,85 & 71,24 & 7,31 \\
\hline \multirow[t]{2}{*}{2017} & 92,84 & 88,03 & 5,18 & 74,73 & 70,63 & 5,50 \\
\hline & \multicolumn{6}{|c|}{ średnie zawodowe } \\
\hline 2004 & 94,56 & 81,33 & 13,99 & 78,49 & 61,60 & 21,52 \\
\hline 2008 & 93,94 & 89,80 & 4,41 & 72,23 & 66,01 & 8,61 \\
\hline 2012 & 95,92 & 88,57 & 7,66 & 71,66 & 61,51 & 14,17 \\
\hline 2016 & 96,11 & 90,98 & 5,34 & 73,88 & 68,04 & 7,90 \\
\hline \multirow[t]{2}{*}{2017} & 96,00 & 92,44 & 3,70 & 69,15 & 64,22 & 7,14 \\
\hline & \multicolumn{6}{|c|}{ zasadnicze zawodowe } \\
\hline 2004 & 94,70 & 74,90 & 20,91 & 70,30 & 50,70 & 27,87 \\
\hline 2008 & 92,23 & 85,02 & 7,82 & 65,33 & 58,11 & 11,05 \\
\hline 2012 & 91,51 & 79,18 & 13,47 & 63,08 & 50,06 & 20,63 \\
\hline 2016 & 92,18 & 83,35 & 9,58 & 56,24 & 48,81 & 13,20 \\
\hline 2017 & 92,21 & 84,32 & 8,56 & 55,00 & 50,00 & 9,08 \\
\hline
\end{tabular}

Źródło: obliczenia własne na podstawie danych indywidualnych BAEL. 
Nieco odmiennie przedstawiała się sytuacja kobiet. Młode kobiety z wykształceniem zasadniczym zawodowym tylko w około połowie są zatrudnione, ogromna zaś ich część - $45 \%$ - pozostaje bierna zawodowo. W przypadku młodych kobiet mających wykształcenie średnie zawodowe udział biernych wynosi $31 \%$. Wydaje się, że kobiety z wykształceniem zawodowym stosunkowo często poświęcają się obowiązkom domowym i rodzicielskim, w ich gospodarstwach domowych tradycyjny podział ról realizuje się zdecydowanie częściej niż wśród osób z innym typem wykształcenia. Bierność młodych kobiet może być spowodowana nie tylko relatywnie niskim wynagrodzeniem, które ogranicza możliwość korzystania z rynkowej oferty usług zastępujących pracę domową, w tym opiekuńczych, ale i trudnościami w podejmowaniu pracy - stopa bezrobocia młodych kobiet w porównaniu do mężczyzn w 2017 r. była dla posiadających wykształcenie średnie zawodowe aż o $63 \%$ wyższa, dla mających wykształcenie zasadnicze różnica ta była mniejsza - 10\%, ale to wynik ich niskiej aktywności zawodowej. W sumie aż połowa młodych kobiet z wykształceniem zasadniczym zawodowym nie pracowała.

\section{Sytuacja młodych osób $\mathrm{z}$ wykształceniem zawodowym na rynku pracy w różnych typach jednostek osiedleńczych}

Młode osoby z wykształceniem średnim zawodowym na ogół znajdują pracę niezależnie od tego, gdzie zamieszkują. Stopa bezrobocia dla nich waha się od 4,1\% w miastach liczących powyżej 100 tys. mieszkańców do 5,8\% w miastach, których liczba mieszkańców nie przekracza 20 tys. (tabela 12). Stosunkowo trwałą cechą rynku pracy dla tych osób jest to, że najtrudniej im o pracę w małych miastach - w latach pokryzysowych stopa bezrobocia przekraczała w nich $12 \%$, gdy na wsi wynosiła niecałe $10 \%$, a w największych miastach niespełna $8 \%$. Po części wynika to $z$ ogólnych trudności w znajdowaniu pracy przez młodych w małych ośrodkach miejskich, gdzie popyt na pracę utrzymuje się na stosunkowo niskim poziomie. W porównaniu z całą populacją młodych osób okazuje się, że osoby mające średnie wykształcenie zawodowe i tak, mimo relatywnie wysokiego bezrobocia w małych miastach, radzą sobie lepiej, gdyż stopa bezrobocia jest tam niższa od przeciętnej dla wieku 25-34 lata o 11\%. Z kolei w miastach liczących ponad 100 tys. mieszkańców w porównaniu z ogółem młodych osób ich sytuacja wydaje się przeciętna, jeśli chodzi o bezrobocie. Zarazem jest ono jednak najniższe 
dla osób z takim wykształceniem, a w dodatku aktywność zawodowa i zatrudnienie najwyższe.

Tabela 12. Podstawowe wskaźniki rynku pracy w 2017 r. dla osób z wykształceniem zawodowym w wieku 25-34 lata według typów jednostek osiedleńczych

\begin{tabular}{|c|c|c|c|c|c|c|}
\hline \multirow[b]{2}{*}{ rok } & \multicolumn{3}{|c|}{ średnie zawodowe } & \multicolumn{3}{|c|}{ zasadnicze zawodowe } \\
\hline & $\begin{array}{c}\text { współczynnik } \\
\text { aktywności } \\
\text { zawodowej }\end{array}$ & $\begin{array}{c}\text { wskaźnik } \\
\text { zatrudnienia }\end{array}$ & $\begin{array}{c}\text { stopa } \\
\text { bezrobocia }\end{array}$ & $\begin{array}{c}\text { współczynnik } \\
\text { aktywności } \\
\text { zawodowej }\end{array}$ & $\begin{array}{c}\text { wskaźnik } \\
\text { zatrudnienia }\end{array}$ & $\begin{array}{c}\text { stopa } \\
\text { bezrobocia }\end{array}$ \\
\hline & \multicolumn{6}{|c|}{ wysokość wskaźników } \\
\hline wieś & 84,35 & 80,26 & 4,85 & 80,63 & 74,29 & 7,86 \\
\hline miasto $<20$ tys. & 88,06 & 82,97 & 5,78 & 75,45 & 68,91 & 8,67 \\
\hline $\begin{array}{l}\text { miasto } \\
20-100 \text { tys. }\end{array}$ & 84,28 & 80,51 & 4,48 & 79,00 & 70,48 & 10,79 \\
\hline \multirow[t]{2}{*}{ miasto > 100 tys. } & 90,01 & 86,28 & 4,15 & 80,94 & 72,93 & 9,91 \\
\hline & \multicolumn{6}{|c|}{ stosunek wskaźników według wykształcenia do wskaźników dla całej populacji } \\
\hline wieś & 1,04 & 1,05 & 0,84 & 0,99 & 0,97 & 1,36 \\
\hline miasto $<20$ tys. & 1,08 & 1,09 & 0,89 & 0,92 & 0,90 & 1,33 \\
\hline $\begin{array}{l}\text { miasto } \\
20-100 \text { tys. }\end{array}$ & 1,01 & 1,02 & 0,78 & 0,94 & 0,89 & 1,89 \\
\hline miasto $>100$ tys. & 1,02 & 1,02 & 1,00 & 0,92 & 0,86 & 2,39 \\
\hline
\end{tabular}

Źródło: obliczenia własne na podstawie: danych indywidualnych BAEL.

Inna jest sytuacja osób z wykształceniem zasadniczym. Im większe miasto, tym - w porównaniu do innych grup zawodowych - jest im ciężej znaleźć pracę. Stopa bezrobocia osób w wieku 25-34 lata posiadających wykształcenie zasadnicze zawodowe w miastach liczących ponad 100 tys. mieszkańców 2,4-krotnie przekracza średnią stopę bezrobocia dla tej grupy wieku. Równie wysoka jest (też bezwzględnie) stopa bezrobocia w miastach o liczbie mieszkańców 20-100 tys. A to wszystko przy niższej niż średnio aktywności zawodowej. Jeszcze raz potwierdza się obserwacja, że młode osoby z wykształceniem zasadniczym są stosunkowo mniej aktywne zawodowo i znajdują pracę raczej na wsi i w małych miastach. 


\section{Charakter zatrudnienia osób}

\section{z wykształceniem zawodowym}

Osoby posiadające wykształcenie średnie zawodowe są najczęściej zatrudnione na stanowiskach techników i innego średniego personelu jako pracownicy usług i sprzedawcy, robotnicy przemysłowi i rzemieślnicy, a także jako operatorzy i monterzy maszyn i urządzeń. W tych czterech grupach zawodowych łącznie pracuje $66,6 \%$ osób z tym wykształceniem (tabela 13).

Jest to dość zaskakująca struktura zawodowa przede wszystkim dlatego, że jej znaczną część stanowią zawody dość proste, robotnicze, które wprawdzie mogą być wykonywane przez osoby z wykształceniem średnim, ale wystarczające byłoby też wykształcenie zasadnicze zawodowe. Według twórców klasyfikacji zawodowej (Klasyfikacja zawodów i specjalności... 2014) zawody te wymagają edukacji na poziomie ponadgimnazjalnym. Być może to efekt zmieniających się wymagań zawodowych stawianych przez pracodawców, którym nie wystarczają już kompetencje szkół niższych poziomów. Może to być również rezultat trudności w znalezieniu pracy odpowiadającej posiadanym kwalifikacjom. Podejmowanie pracy na niższych stanowiskach, niż wynika to ze zdobytych kwalifikacji dla osób je posiadających, musi być niekorzystne prestiżowo, rozwojowo i finansowo. $Z$ drugiej zaś strony oznacza, że mający wyższe kwalifikacje konkurują o miejsca pracy z osobami niżej wykwalifikowanymi, wypierając je z miejsc odpowiednich dla nich pod względem kompetencji. 
Tabela 13. Struktura zatrudnienia w 2017 r. osób z wykształceniem zawodowym

w wieku 25-64 lata

\begin{tabular}{l|c|c|c|c} 
grupa zawodowa & $\begin{array}{c}\text { kategoria } \\
\text { ISCED* }\end{array}$ & $\begin{array}{c}\text { średnie } \\
\text { zawodowe } \\
(\mathrm{w} \%)\end{array}$ & $\begin{array}{c}\text { zasadnicze } \\
\text { zawodowe } \\
(\mathrm{w} \%)\end{array}$ & $\begin{array}{c}\text { ogółem } \\
(\mathrm{w} \%)\end{array}$ \\
\hline $\begin{array}{l}\text { przedstawiciele władz publicznych, } \\
\text { wyżsi urzędnicy i kierownicy }\end{array}$ & $3,4,5,6,7,8$ & 5,23 & 1,49 & 6,52 \\
\hline specjaliści & $5,6,7,8$ & 4,44 & 0,11 & 20,25 \\
\hline technicy i inny średni personel & 3,4 & 18,28 & 2,58 & 13,21 \\
\hline pracownicy biurowi & 3,4 & 7,09 & 3,05 & 6,02 \\
\hline pracownicy usług i sprzedawcy & 3,4 & 17,36 & 12,73 & 12,39 \\
\hline rolnicy, ogrodnicy, leśnicy i rybacy & 3 & 9,88 & 17,15 & 8,95 \\
\hline robotnicy przemysłowi i rzemieślnicy & 3 & 17,34 & 32,12 & 15,01 \\
\hline operatorzy i monterzy maszyn i urządzeń & 2,3 & 13,63 & 18,62 & 10,37 \\
\hline pracownicy wykonujący prace proste & 1,2 & 5,85 & 12,04 & 6,64 \\
\hline siły zbrojne & $2,3,4,5,6,7,8$ & 0,90 & 0,11 & 0,64 \\
\hline ogółem & - & 100 & 100 & 100
\end{tabular}

* ISCED - Międzynarodowa Standardowa Klasyfikacja Wykształcenia.

Źródło: obliczenia własne na podstawie danych indywidualnych BAEL.

Niewielka część osób z wykształceniem średnim zawodowym $(4,4 \%)$ pracuje na stanowiskach z wyższymi wymaganiami zawodowymi - specjalistów, gdzie zasadniczo oczekuje się wykształcenia wyższego. Inna, podobna co do wielkości grupa, pełni funkcje kierownicze $(5,2 \%)$.

Osoby z wykształceniem zasadniczym zawodowym to głównie robotnicy przemysłowi i rzemieślnicy - aż 32,1\% pracuje w tym charakterze. Ale też operatorzy maszyn i urządzeń, rolnicy, ogrodnicy i rybacy, a także pracownicy usług i sprzedawcy. W tych czterech grupach zawodowych wykonuje pracę aż 80,6\%. Część osób z wykształceniem zasadniczym podejmuje prace proste, gdyby je uwzględnić, to wyczerpuje się katalog zajęć zawodowych podejmowanych przez osoby z tym typem wykształcenia. 
Wykres 12. Udział osób z wykształceniem zawodowym w grupie wszystkich zatrudnionych w grupach zawodowych w 2017 r., wiek 25-64 lata (w \%)

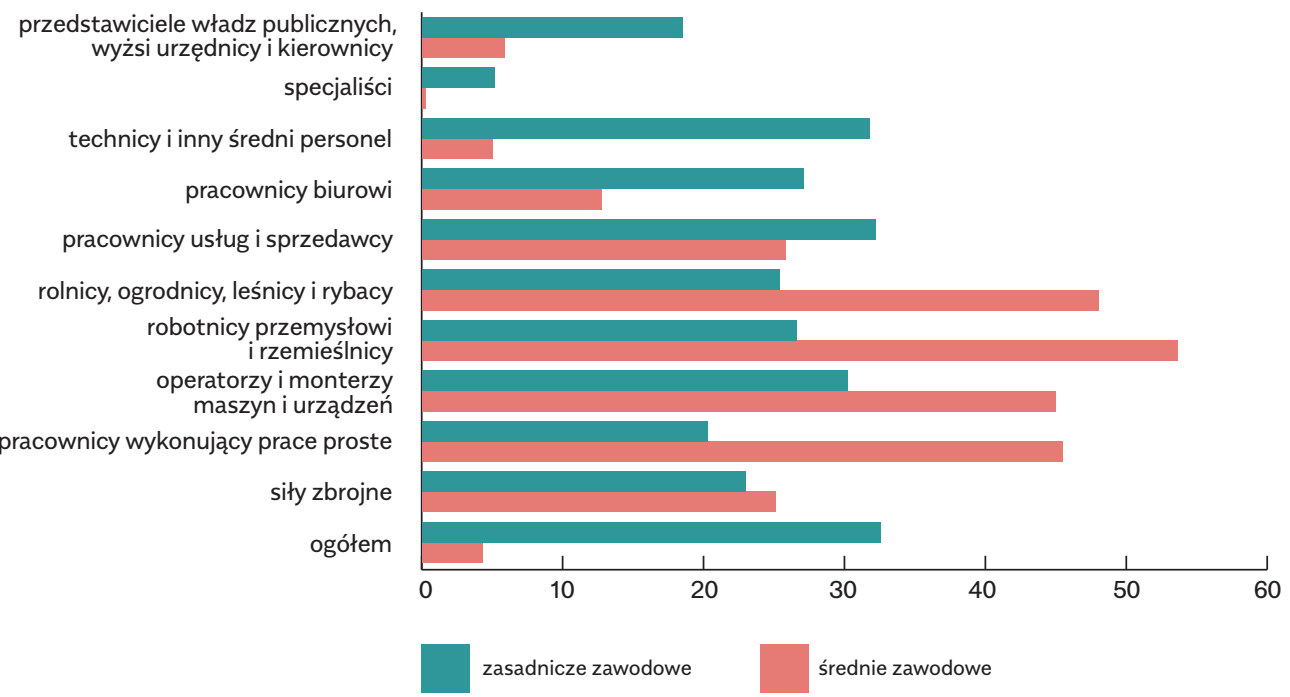

Źródło: obliczenia własne na podstawie: danych indywidualnych BAEL.

W przypadku prac prostych wykształcenie zasadnicze, a tym bardziej średnie zawodowe, nie jest konieczne, niemniej nie sposób nie zauważyć, że osoby z wykształceniem zasadniczym i średnim zawodowym zajmują zdecydowaną większość takich miejsc pracy, bo aż $65,7 \%$ (wykres 12). Większościowy udział mają też na stanowiskach robotników wykwalifikowanych i rzemieślników (razem 80,2\%, z czego $1 / 3$ przypada na osoby posiadające wykształcenie średnie), operatorów i monterów maszyn i urządzeń $(75,2 \%$, w tym $2 / 5$ to osoby z wykształceniem średnim), rolników, ogrodników, leśników i rybaków (73,4\%, w tym 1/3 z wykształceniem średnim). Licznie też występują wśród pracowników usług i sprzedawców $(57,9 \%$, z czego większość ma średni poziom wykształcenia). Wymienione wyżej grupy stanowisk opierają swoje istnienie na zatrudnieniu osób z wykształceniem zawodowym. Różnorodność wykonywanych zawodów cechuje przede wszystkim osoby ze średnim wykształceniem zawodowym, co odpowiada w jakimś stopniu dość zróżnicowanej strukturze kształcenia zawodowego na tym poziomie. Bardziej skoncentrowane w niektórych 
dziedzinach kształcenie zasadnicze odpowiada na rynku pracy węższej gamie zajęć zawodowych. Ale nawet w tym przypadku różnorodność jest znaczna, a to stanowi wyzwanie dla szkolnictwa zawodowego, jeśli ma przygotowywać do tak wielu zajęć zawodowych. Z innej zaś strony realia gospodarcze każą liczyć się z koniecznością podejmowania pracy na stanowiskach, na których nie wszystkie posiadane kompetencje mogą być wykorzystane.

\section{Podsumowanie i wnioski}

Mimo znaczącego upowszechnienia się kształcenia na poziomie wyższym osoby z wykształceniem zawodowym, zarówno zasadniczym, jak i średnim, stanowią największą część zasobów pracy w Polsce. Przy tym odsetek osób z wykształceniem zasadniczym znacząco się zmniejszył, natomiast udział aktywnych zawodowo $z$ wykształceniem średnim zawodowym utrzymuje się na stabilnym poziomie. W 2017 r. osoby posiadające wykształcenie zawodowe zasadnicze i średnie stanowiły aż $47 \%$ zasobów pracy w wieku 25-64 lata. Jednocześnie było to o 10 pkt. proc. mniej niż jeszcze w 2004 r. Można domniemywać, że spadek ten jest wynikiem zmian demograficznych, modyfikacji wzorców kształcenia, a także zmian opłacalności dysponowania wykształceniem zawodowym na rynku pracy oraz migracji. Zmniejszenie udziału osób z zawodowym wykształceniem średnim i zasadniczym w mniejszym stopniu wynikało z zachowań edukacyjnych mężczyzn niż kobiet. Mężczyźni tradycyjnie często podejmowali naukę w średnich szkołach zawodowych, trochę rzadziej uczyli się w szkołach zasadniczych. W porównaniu do kobiet częściej poprzestawali na wykształceniu gimnazjalnym lub niższym. Kobiety zaś w większym stopniu preferowały studia wyższe i kształcenie średnie ogólne.

To, że w ostatnich dekadach udział wykształcenia średniego zawodowego w strukturze wykształcenia ludności nie zmieniał się gwałtownie, wynikało z przeciwstawnych tendencji-zmniejszania się tego udziału w miastach i zwiększania się go na wsi. Może to przekładać się na zwiększenie niedopasowania strukturalnego popytu i podaży pracy powodujące nie tylko bezrobocie na obszarach mniej zurbanizowanych, ale też istotne problemy pracodawców z zapełnieniem wakatów. $Z$ kolei im mniejszy ośrodek, tym udział osób posiadających wykształcenie zasadnicze był większy. 
Zdecydowana większość osób z wykształceniem zawodowym uzyskała je w dziedzinach związanych z techniką, przemysłem lub budownictwem. W przypadku wykształcenia średniego zawodowego obserwujemy większą dywersyfikację, jeśli chodzi o kierunki kształcenia. Jednocześnie postępuje proces zawężania dziedzinowych wyborów w kształceniu zasadniczym zawodowym. Ubyło wykształconych na poziomie średnim $w$ dziedzinach społecznej, zdrowia, rolnictwa. Zmiany struktury kształcenia zawodowego w obrębie szkół średnich i zasadniczych do pewnego stopnia odpowiadają zmianom w zatrudnieniu. Większą różnorodnością cechuje się zatrudnienie osób z wykształceniem zawodowym średnim niż zasadniczym. Zarazem obserwujemy trudność w podejmowaniu pracy na stanowiskach odpowiadającym poziomowi wykształcenia. Dość znaczna część dysponujących wykształceniem średnim zajmuje stanowiska, do których - zgodnie z klasyfikacją zawodową - powinno wystarczać wykształcenie zasadnicze, z kolei część osób posiadających wykształcenie zasadnicze zawodowe pracuje w miejscach, gdzie też nie jest ono potrzebne.

Badania pracodawców od kilku lat wskazują, że wiele nowych miejsc pracy powstaje na stanowiskach robotników przemysłowych oraz operatorów maszyn i urządzeń, a także na stanowiskach, na których wymaga się przede wszystkim średniego wykształcenia zawodowego - techników i średniego personelu oraz pracowników biurowych. Są to także te typy stanowisk, gdzie pracodawcy zgłaszają istotne trudności w znalezieniu kandydatów do pracy, posiadających specyficzne kompetencje zawodowe, a także ogólne. Przekłada się to na często podnoszony postulat zwiększenia kształcenia zawodowego. Może być on prawdziwy, ale chyba tylko częściowo. Trzeba bowiem zwrócić uwagę, że znaczącym problemem w tych grupach wykształcenia pozostaje systematyczna nierównowaga wyrażająca się biernością i bezrobociem z jednej strony (zwłaszcza w przypadku wykształcenia zasadniczego zawodowego), a z drugiej podejmowaniem pracy na stanowiskach o mniejszych wymaganiach kwalifikacyjnych niż posiadane. Inną przyczyną są też relatywnie niskie płace (rozdział 2), a zatem niedostateczna wielkość oferowanej podaży pracy może być skutkiem niskiej atrakcyjności zatrudnienia w tych zawodach i wysokich kosztów alternatywnych.

Mimo problemów pracodawców ze znalezieniem pracowników, osoby posiadające wykształcenie zasadnicze ponadprzeciętnie często tra- 
fiali do bezrobocia. Odnosi się to zwłaszcza do osób młodych. Może to sugerować ich niedopasowanie do oczekiwań pracodawców pod względem kompetencji lub problemy z mobilnością przestrzenną, potęgowane niskim poziomem wynagrodzeń. Wyraźnie w lepszej sytuacji (także lepszej niż przeciętny uczestnik rynku pracy w Polsce) znajdują się osoby z wykształceniem średnim zawodowym.

Warto zauważyć, że w Polsce są nadal znaczne grupy osób, które mogłyby podjąć kształcenie zawodowe. Osoby bez wykształcenia zawodowego stanowią wciąż ponad $16 \%$, z czego ok. 8,5\% z wykształceniem licealnym, a ponad $7,5 \%$ z wykształceniem co najwyżej gimnazjalnym. 